\title{
Advances in Tissue Engineering and Innovative Fabrication Techniques for 3-D-Structures: Translational Applications in Neurodegenerative Diseases
}

\author{
Federica Rey ${ }^{1,2}{ }^{-}$, Bianca Barzaghini ${ }^{3}$, Alessandra Nardini ${ }^{3}$, Matteo Bordoni ${ }^{4}$, \\ Gian Vincenzo Zuccotti ${ }^{1,2}$ (D) , Cristina Cereda ${ }^{5}$, Manuela Teresa Raimondi ${ }^{3, *}$ and \\ Stephana Carelli ${ }^{1,2, *(1)}$ \\ 1 Department of Biomedical and Clinical Sciences "L. Sacco", University of Milan, Via Grassi 74, \\ 20157 Milan, Italy; federica.rey@unimi.it (F.R.); gianvincenzo.zuccotti@unimi.it (G.V.Z.) \\ 2 Pediatric Clinical Research Center Fondazione "Romeo ed Enrica Invernizzi", University of Milano, \\ Via Grassi 74, 20157 Milano, Italy \\ 3 Department of Chemistry, Materials and Chemical Engineering "Giulio Natta", Politecnico di Milano, \\ Piazza Leonardo da Vinci 32, 20133 Milano, Italy; bianca.barzaghini@polimi.it (B.B.); \\ alessandra.nardini@mail.polimi.it (A.N.) \\ 4 Dipartimento di Scienze Farmacologiche e Biomolecolari (DiSFeB), \\ Centro di Eccellenza sulle Malattie Neurodegenerative, Università degli Studi di Milano, Via Balzaretti 9, \\ 20133 Milano, Italy; matteo.bordoni@unimi.it \\ 5 Genomic and post-Genomic Center, IRCCS Mondino Foundation, Via Mondino 2, 27100 Pavia, Italy; \\ cristina.cereda@mondino.it \\ * Correspondence: manuela.raimondi@polimi.it (M.T.R.); stephana.carelli@unimi.it (S.C.); \\ Tel.: +390-223-994-306 (M.T.R.); +390-250-319-825 (S.C.)
}

Received: 8 June 2020; Accepted: 6 July 2020; Published: 7 July 2020

\begin{abstract}
In the field of regenerative medicine applied to neurodegenerative diseases, one of the most important challenges is the obtainment of innovative scaffolds aimed at improving the development of new frontiers in stem-cell therapy. In recent years, additive manufacturing techniques have gained more and more relevance proving the great potential of the fabrication of precision 3-D scaffolds. In this review, recent advances in additive manufacturing techniques are presented and discussed, with an overview on stimulus-triggered approaches, such as 3-D Printing and laser-based techniques, and deposition-based approaches. Innovative 3-D bioprinting techniques, which allow the production of cell/molecule-laden scaffolds, are becoming a promising frontier in disease modelling and therapy. In this context, the specific biomaterial, stiffness, precise geometrical patterns, and structural properties are to be considered of great relevance for their subsequent translational applications. Moreover, this work reports numerous recent advances in neural diseases modelling and specifically focuses on pre-clinical and clinical translation for scaffolding technology in multiple neurodegenerative diseases.
\end{abstract}

Keywords: additive manufacturing; scaffold geometry; disease modeling; cell therapy; stem cells; neurodegenerative diseases; 3-D structures; regenerative medicine 


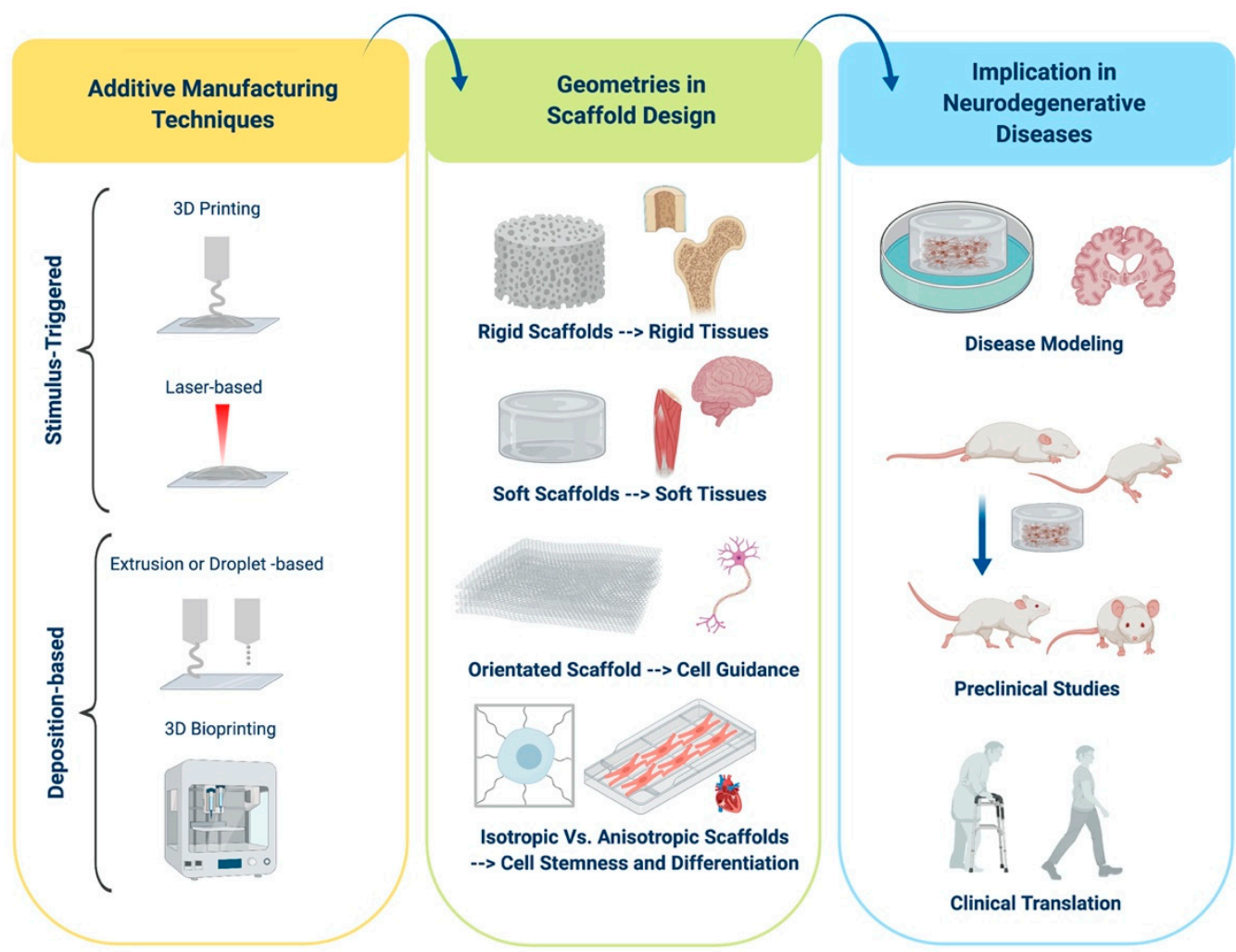

Made in @BioRender-biorender.com

\section{Introduction to Scaffold Design}

The field of tissue engineering relies on the use of three-dimensional scaffolds as templates for tissue formation [1]. Scaffolds are typically defined as complex 3-D structures whose purpose is to provide a favorable environment for cells' adhesion and growth, and to give structural support when implanted "in vivo" [2,3]. These structures are gaining more and more relevance in cell biology and tissue engineering as the development of new biomaterials and 3-D scaffolds exhibits a lot of potential in the production of functional 3-D structures with increased biomimetic features [3-5].

\subsection{Scaffold Features}

The design of scaffold architecture must be tissue specific in terms of porosity (pore shape and size), morphology (interconnection and fibers' orientation), and surface topography (shape and roughness) [6]. These features are essential to improve cell homing (adhesion, survival, migration, differentiation) and to facilitate the flow of culture medium (in vitro) or blood (in vivo) through the construct in order to ensure the supply of nutrients and oxygenation $[2,6]$. When implanted, the engineered scaffold must be biocompatible in order to avoid both immune reactions and inflammatory responses, as well as the toxicity of the products of degradation for biodegradable scaffolds. The scaffold should have equivalent mechanical properties to that of the native tissue, in terms of stiffness and structural stability, as these influence cells' adhesion, proliferation, and differentiation. Moreover, the scaffold's degradation kinetics has to be balanced with the new tissue formation [2]. These characteristics are of great importance to adequately support the regeneration process of the recipient tissue or organ [3].

\subsection{Approaches to Tissue Engineering}

Tissue engineering is mainly based on two approaches: Top-down or bottom-up (Figure 1). The first one employs additive manufacturing (AM) techniques, which are advanced manufacturing processes based on the sequential addition of material, in order to produce 3-D scaffolds with the 
appropriate architecture to guide the formation of the desired tissue. In this case, living cells are seeded on or within the porous 3-D structures $[3,7,8]$. The main advantages of top-down strategies are the possibility to use a wide range of processing materials and the production of porous scaffolds with specific mechanical properties according to the applications of interest. On the other hand, the lack of proper vascularization of the construct, the challenges in a homogeneous distribution of multiple cell types, and the subsequent impossibility to achieve tissue specific cell densities represent some serious limitations $[3,6,9,10]$. In bottom-up approaches, scaffolding materials, cells, and sometimes also bioactive factors are assembled together, forming building units of several shapes and sizes [11]. Using different bottom-up processes, such as hydrogel encapsulation, self-assembled cell aggregation, cell sheets, and 3-D bioprinting, it is possible to achieve constructs with more complex functions $[3,12]$. Recently, bottom-up approaches have gained more and more relevance because they allow for an optimal control over the spatial arrangement of cells, obtaining an architecture that could strictly mimic the organization of the native tissue $[9,12]$. However, these processing techniques are often relatively slow, making the assembly of larger tissues challenging. In addition, bottom-up techniques usually use materials with low mechanical properties (e.g., in the range of $0.2-1700 \mathrm{kPa}$ for hydrogels composed of various biomaterials [13]), suitable to reproduce extracellular matrix (ECM) features but limiting the structural aspect of the construct [9]. Both tissue engineering approaches will benefit from the development of innovative AM techniques, which could be helpful in the production of realistic ECM-like scaffolds [3,12].

\section{Top-Down approach}

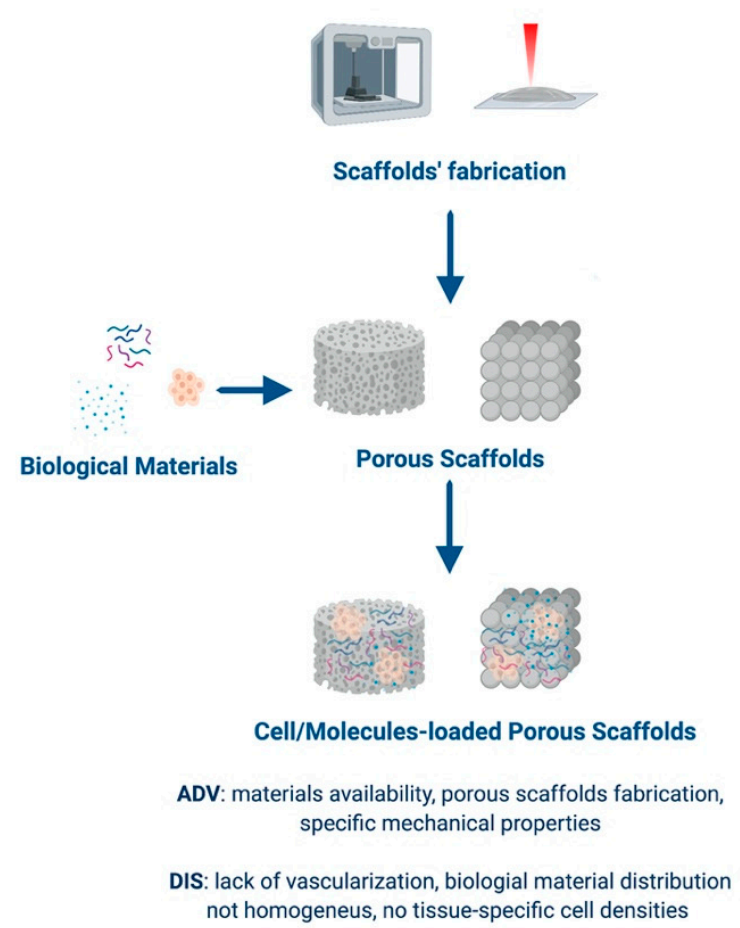

\section{Bottom-Up approach}

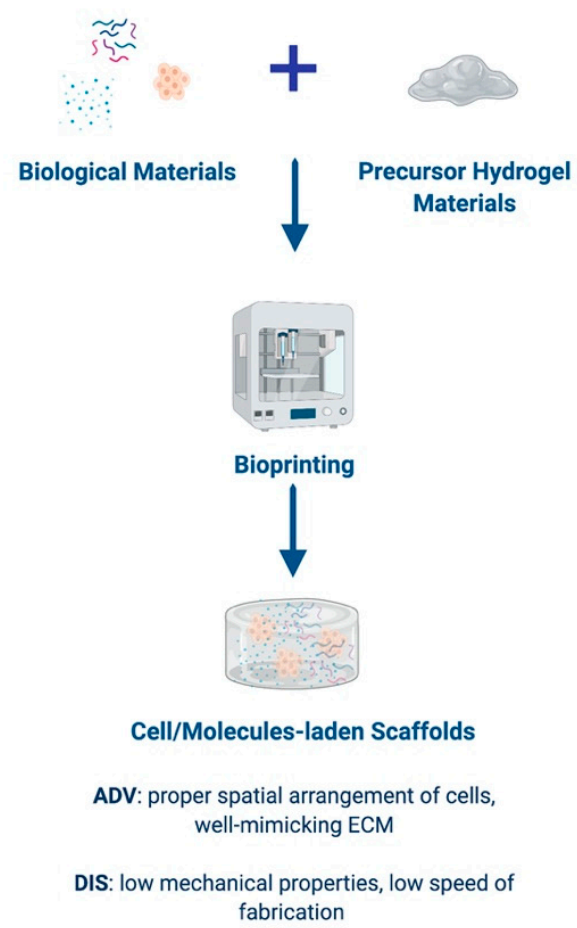

Figure 1. Schematization of the approaches applied in additive manufacturing (AM) techniques. On the left, the top-down approach is shown, which employs AM techniques to produce 3-D scaffolds with the appropriate architecture to guide the formation of the desired tissue. In this case, living cells are seeded on or within the porous 3-D structures. On the right, the bottom-up approach is described, where scaffolding materials, cells, and sometimes also bioactive factors are assembled together, forming building units of several shapes and sizes. Advantages (ADV) and disadvantages (DIS) of each technique are also reported. Made in (CBioRender-biorender.com. 


\subsection{Classes of Biomaterials}

Biomaterials used for scaffold fabrication are usually classified in synthetic polymers, natural polymers, and ceramics [2]. Synthetic polymers are processed using a wide range of assembly approaches as they are not present in nature. Thanks to their great processing flexibility and ease of manipulation, this class of materials is widely used to produce structures with tailored architecture, appropriate mechanical properties, and controlled degradation features according to application-specific requirements $[14,15]$. These features can be achieved by acting on the molecular weight distribution of the material and varying the monomer composition of copolymers [16]. A reduced bioactivity, meaning a lack of interaction between the tissue and the synthetic scaffold, derived from the inability to combine the material with bioactive molecules because of low affinity, is the main limitation of the synthetic polymers [2,3]. Despite a minimal immune response, polylactic acid (PLA), polyglycolic acid (PGA), and poly(lactic-co-glycolic acid (PLGA) are among the few synthetic polymers Food and Drug Administration (FDA)-approved for clinical applications [17-19]. In particular, PLGA, thanks to its adaptable design and the capacity to provide bioactive signals to enhance cell-biomaterial interaction, is one of the most common synthetic polymers in clinical use for bone and cartilage tissue regeneration [20]. Natural polymers are convenient in tissue engineering for their excellent biocompatibility, and their ability to promote cell adhesion and growth [2]. Biological materials, such as alginate, hyaluronic acid, and chitosan, are polysaccharide based or a derivative from proteins, such as collagen, fibrin, and silk. This kind of polymers are widely available in nature and their biodegradability, in addition to their bioactivity, closely mimics that of the ECM [21].

Natural polymers promote minimal inflammatory and immune responses [3]. However, whilst being processed, the materials often lose their biological functions, making the fabrication of scaffolds with homogeneous and repeatable structures challenging [2]. In addition, natural polymer-derived scaffolds generally have poor mechanical properties, which limit their application in mechanical load-bearing anatomical sites, such as in hard tissue regeneration. The combination of natural biomaterials with synthetic ones to produce hybrid scaffolds of multiple phases is an attractive solution to overcome all these limitations [3,22,23]. Ceramic materials can be classified as nearly inert (alumina and zirconia), bioactive (based on bioactive glass), and resorbable (based on alpha and beta tricalcium phosphate) [3]. Bioceramic scaffolds are commonly used in bone tissue regeneration thanks to their biocompatibility and bioactivity, along with the possibility to achieve hierarchical structures at micro and nano scales whilst mimicking the native tissue well [24]. They are characterized by high mechanical stiffness and low elasticity. Their brittleness and tricky machining processability into specific shapes, in addition to the mechanical properties previously underlined, limit their clinical applications [25]. Moreover, the degradation kinetics of ceramic scaffolds does not match the new bone formation [2,3]. The assembly of polymers and ceramic materials promotes greater flexibility to the final construct, rendering it more similar to the native tissue, offering biological benefits as well as an improvement of the mechanical properties [26]. To support and improve the regeneration of hard tissues and to produce parts with highly complex geometries, metallic materials are commonly used. They can be of relevance in the field of regenerative medicine and are mainly employed in the production of medical implants [7]. Another innovative strategy relies on the use of decellularized ECM as a template for tissue regeneration. The decellularization process relies on the enzymatic, chemical, or physical removal of the entire cellular part, whilst maintaining the original ECM's structural integrity and tissue's vasculature network, thus preserving the design features at the micro and nano scale [27]. For these reasons, ECM-based scaffolds provide an ideal environment for cell adhesion and growth, similar to that of the native tissue [28]. On the other hand, the low availability of donors and the accelerated degradation, which leads to the lack of a cell repopulation and tissue remodeling, are limitations that need to be overcome before ECM-based scaffolds become applicable [3,29].

\section{Fabrication Techniques}

Additive manufacturing (AM) techniques are proving to have great potential in the fabrication of precision biomaterials as they overcome the limits of traditional subtractive manufacturing techniques, 
typically based on material removal from a solid block to generate the final construct $[6,7,30,31]$. Indeed, AM techniques are free-form processes as they rely on sequential addition of material to form the 3-D structure. These advanced processing methods allow freedom of design, the production of scaffolds with complex geometries, and they could provide patient-specific fabrications. These are at the basis of personalized medicine, where the curing agent is developed to fit the immune compatibility and the therapeutic need of the patient $[7,31,32]$. AM techniques could be classified as stimulus-triggered AM and deposition-based AM, according to the introduction of a trigger or the direct deposition of the material during the process. In stimulus-triggered AM, the biofunctionality of the final construct could be influenced by the nature of the stimulus applied; for this reason, cells and bioactive molecules are usually added post fabrication, making this a typically top-down approach. Despite the high processing speeds and high spatial resolutions achieved, stimulus-triggered AM does not allow the production of multi-material scaffolds. On the other hand, deposition-based AM enable the direct fabrication of cell-laden constructs, and cell survival is ensured by properly controlling process parameters and material design constraints [7]. These techniques were born as top-down approaches. Even if these approaches are still utilized, new technologies, grouped as "3-D bioprinting techniques", were also developed and represent an exception, as they allow for the direct encapsulation of biological materials and are thus bottom-up approaches. Deposition-based AM also presents with some disadvantages, such as a loss in resolution and a relatively slow speed of processing [7,33,34]. A summary of these techniques is illustrated in Figure 2 and a more comprehensive overview is reported in Table 1.

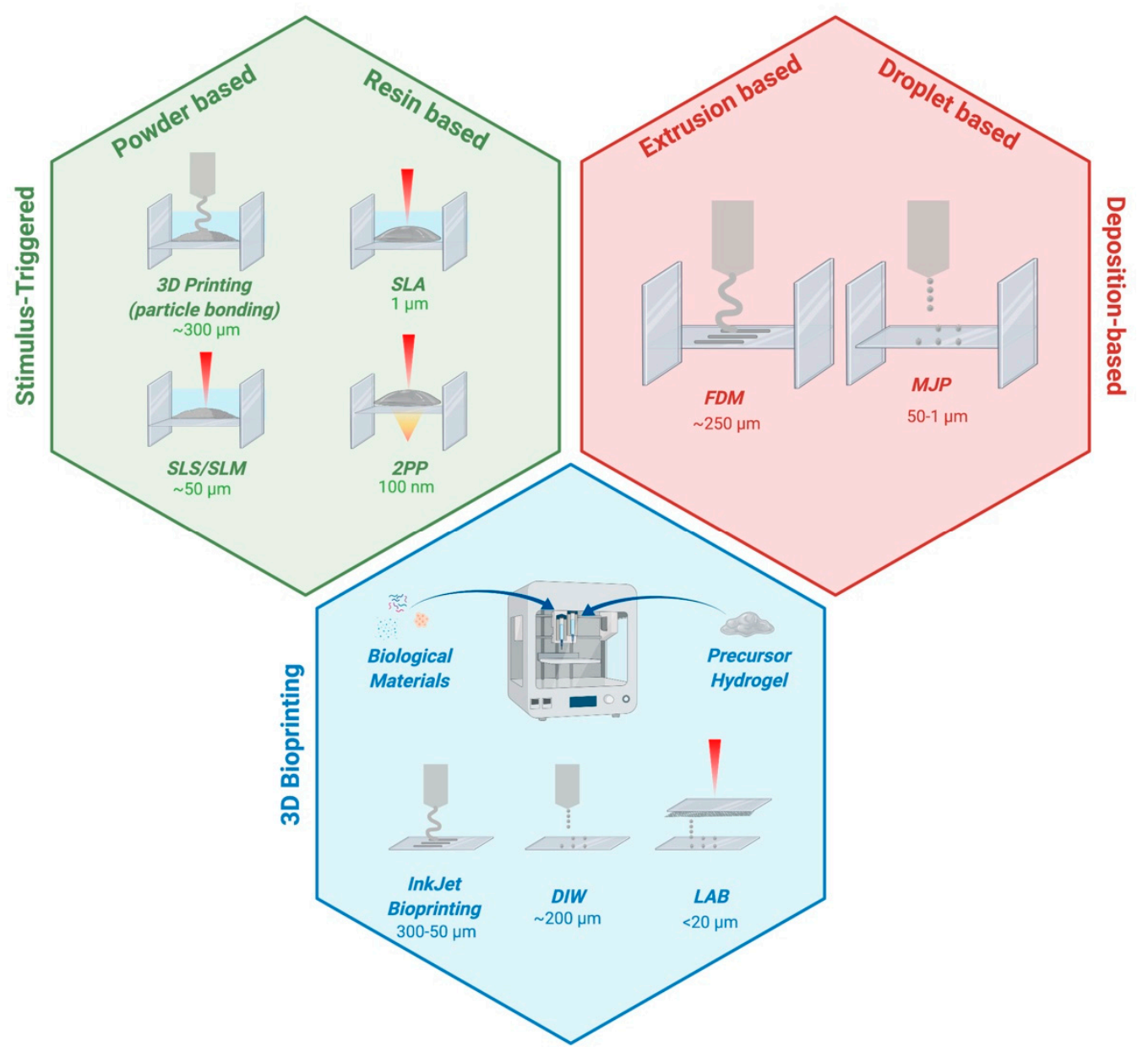

Figure 2. Summary of the three main categories of additive manufacturing techniques for scaffold fabrication. The top left hexagon reports the different stimulus-triggered approaches, subdividing them 
into powder based (3-D printing and SLS/SLM) and resin based (SLA and 2PP). The top right exagon reports the two main categories of deposition-based techniques: extrusion based (FDM) and droplet based (MJP). The lower central hexagon refers to the different types of 3-D bioprinting: InkJet Bioprinting, DIW, and LAB. Made in CBioRender-biorender.com.

Table 1. Summary of additive manufacturing techniques for scaffold fabrication.

\begin{tabular}{|c|c|c|c|c|c|}
\hline $\begin{array}{l}\text { Fabrication } \\
\text { Approach }\end{array}$ & $\begin{array}{l}\text { Fabrication } \\
\text { Technique }\end{array}$ & $\begin{array}{l}\text { Principle of } \\
\text { Operation }\end{array}$ & Resolution & Advantages & Limitations \\
\hline \multirow{4}{*}{ 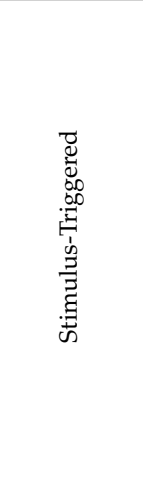 } & $\begin{array}{l}\text { 3-D Printing } \\
\text { (particle } \\
\text { bonding) }\end{array}$ & $\begin{array}{l}\text { Binder solution } \\
\text { ejection on } \\
\text { powder bed }\end{array}$ & $\sim 300 \mu \mathrm{m}$ & $\begin{array}{l}\text { Mix of powder } \\
\text { Controlled architecture }\end{array}$ & $\begin{array}{c}\text { Low spatial resolution } \\
\text { Post-fabrication } \\
\text { treatment } \\
\text { Pore size }\end{array}$ \\
\hline & SLS/SLM & $\begin{array}{l}\text { Locally powder bed } \\
\text { sintering/melting }\end{array}$ & $\sim 50 \mu \mathrm{m}$ & $\begin{array}{l}\text { No supporting structure } \\
\text { No organic solvent } \\
\text { Materials availability }\end{array}$ & $\begin{array}{c}\text { High Temperature } \\
\text { Poor surface accuracy } \\
\text { Poor interconnection } \\
\text { control }\end{array}$ \\
\hline & SLA & $\begin{array}{c}\text { Photopolymerization } \\
\text { of UV-curable } \\
\text { resin at surface }\end{array}$ & $1 \mu \mathrm{m}$ & $\begin{array}{l}\text { Low cost equipment } \\
\text { High processing speed }\end{array}$ & $\begin{array}{l}\text { Polymerization effects } \\
\text { Post-curing treatment }\end{array}$ \\
\hline & $2 \mathrm{PP}$ & $\begin{array}{l}\text { Photopolymerization } \\
\text { of UV-curable } \\
\text { resin at laser focus }\end{array}$ & $100 \mathrm{~nm}$ & $\begin{array}{l}\text { Higher resolution } \\
\text { No controlled } \\
\text { environment }\end{array}$ & Polymerization effects \\
\hline \multirow{2}{*}{ 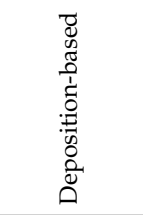 } & FDM & $\begin{array}{l}\text { Fused material } \\
\text { extrusion/solidification } \\
\text { upon cooling }\end{array}$ & $\sim 250 \mu \mathrm{m}$ & $\begin{array}{l}\text { No toxic solvents } \\
\text { Materials availability }\end{array}$ & $\begin{array}{l}\text { Low spatial resolution } \\
\text { High temperatures } \\
\text { Low dimensional } \\
\text { accuracy }\end{array}$ \\
\hline & MJP & $\begin{array}{l}\text { Droplets deposition } \\
\text { of UV-curable resin }\end{array}$ & $50-1 \mu \mathrm{m}$ & High spatial resolution & $\begin{array}{l}\text { Expensive materials } \\
\text { Rheology control }\end{array}$ \\
\hline \multirow{3}{*}{ 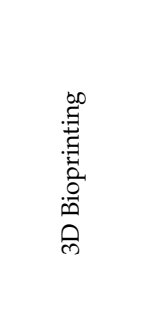 } & $\begin{array}{c}\text { InkJet } \\
\text { Bioprinting }\end{array}$ & $\begin{array}{l}\text { Bio-Ink droplets } \\
\text { deposition }\end{array}$ & $300-50 \mu \mathrm{m}$ & Single cell encapsulation & $\begin{array}{c}\text { Low spatial resolution } \\
\text { Low viscosity } \\
\text { upper limit }\end{array}$ \\
\hline & DIW & Bio-Ink extrusion & $\sim 200 \mu \mathrm{m}$ & $\begin{array}{l}\text { High processing speed } \\
\text { High cellular densities } \\
\text { Larger structures } \\
\text { fabrication }\end{array}$ & $\begin{array}{l}\text { Low spatial resolution } \\
\text { Apoptotic effect (for } \\
\text { mechanical-based } \\
\text { system) }\end{array}$ \\
\hline & LAB & $\begin{array}{l}\text { Laser induced } \\
\text { Bio-Ink droplets } \\
\text { deposition }\end{array}$ & $<20 \mu \mathrm{m}$ & $\begin{array}{l}\text { Good spatial resolution } \\
\text { High bioactivity }\end{array}$ & Rheology control \\
\hline
\end{tabular}

\subsection{Stimulus-Triggered Approaches}

Stimulus-triggered approaches rely on the introduction, during the fabrication process, of a trigger to induce the material's (liquid or powder) solidification and organization in a specific spatial location, defined voxel, in order to form the desired 3-D structures [7]. These techniques can be classified in 3-D printing based on particle bonding and laser-based AM based on the used trigger [7].

\subsubsection{3-D Printing Based on Particle Bonding}

The 3-D printing technique based on particle bonding relies on the ejection of a binder solution on the top of a powder bed, in accordance with a software 3-D model [35]. When the binder is printed, a thin 2-D layer of material is solidified and the powder support moves down as a fresh layer of powder is deposited. This process is sequentially repeated binding a layer to the next leading to a "layer by layer" formation of complex 3-D structures that will later be subjected to a post fabrication treatment in order to remove the embedded unprocessed powder [6-8,36]. This kind of 3-D printing allows the production of porous scaffolds, characterized by channels and overhanging features, with control over the pore architecture by operating on the region of bounding. There is also control over the micro-porosity, which depends on the space between the granules of powder [36]. Moreover, it is possible to use one-component powder or different powders blended together. On the other hand, the spatial resolution achieved is $\sim 300 \mu \mathrm{m}$ and the pore size is limited by the size of the powder used. 
As with other powder-based techniques, 3-D printing based on particle bonding provides a rough surface to the fabricated scaffold, a feature that may be relevant for cells-material interaction [6].

\subsubsection{Laser-Based Techniques}

Laser-based AM are direct laser writing (DLW) techniques, which employ focused light as a stimulus to solidify the material in the specific voxel of the 3-D space [7]. These techniques are based on the excitation of electrons in the atoms and molecules of the fabrication material, induced by photon absorption, or on the photopolymerization phenomenon, which occurs when photons are absorbed by a photo-initiator molecule in the material-forming free radicals [37]. In the first case, energy is converted into heat and, at low energy, localized heating results in sintering or melting of the material, maintaining intact bounds between molecules and avoiding material detachment [38,39]. In the second case, radicalized molecules promote a series of polymerization reactions in the target material [40]. The most important parameter in DLW techniques is the laser wavelength, which, acting on the laser-material interaction, defines the absorption and the scattering of laser radiation in the material. Solid-state lasers, meaning that the active laser medium is solid, usually work from ultraviolet (UV) to infrared (IR) wavelengths and can operate in a continuous wave or in pulsed mode [41]. These two modes of operation differ for the output energy, which is, in the continuous case, constant over time, compared to the pulsed one in which higher energies are involved, emitted over short time pulses [41]. Using continuous lasers, parameters to keep in consideration are the power as the total energy per unit time; the irradiance as the power per unit area; the numerical aperture of the objective used, which influences the final resolution of fabrication; and the duration of laser exposure defined as the time during which the laser emits radiation [37]. In the case of pulsed lasers, important parameters are also the pulse duration, the pulse energy, the repetition rate, the average and peak power, and the fluence, defined as the amount of energy divided by the sample surface per unit area [37]. The use of a laser beam provides focused spatial energy, allowing materials at the micro and sub-micro scale to be processed, creating micro and nano patterns with self-supporting features. For this reason, the main advantage of DLW techniques is the high spatial resolution achieved in addition to the possibility of building complex 3-D architectures, which are of great importance in the field of personalized medicine [41,42]. Moreover, it is possible to use different materials depending on the application and, in some cases, incorporate biological components within the material, avoiding its deterioration [37]. The most investigated laser-based AM techniques are selective laser sintering/selective laser melting (SLS/SLM), stereolithography (SLA), and two photon polymerization (2PP).

\section{Selective Laser Sintering and Selective Laser Melting}

Selective laser sintering (SLS)/selective laser melting (SLM) are both powder-based DLW techniques but differ in the process of 2-D pattern formation, which leads to powder sintering or melting [39]. These approaches rely on the use of continuous lasers, such as $\mathrm{CO}_{2}$ lasers involving high power and long pulse lasers, as they are thermally activated techniques $[43,44]$. The laser beam is focused on a thin layer of powder, which is locally heated by the electromagnetic radiation emitted by the laser, at a temperature at which the granules of the powder sinter or melt together, forming solid 2-D patterns. Moving the adjustable table on which the powder lies and adding fresh powder over the solid 2-D layer previously formed allows the fabrication of 3-D structures; this process is repeated until the structures are complete, leading to a layer-by-layer fabrication. At the end of the process, it is necessary to remove the un-sintered or un-melted powder from the 3-D construct, manually or with brushing and powder blasting, thus avoiding the use of organic solvents [37,41]. The main advantage of SLS/SLM processes is the possibility to construct overhanging regions with no need for support structures thanks to the unfused powder outside the sintered/melded one that, remaining within the fabricated volume, acts and supports material. Using a focused laser SLS/SLM AM achieves a spatial resolution of $\sim 50 \mu \mathrm{m}$ and the laser's high energy allows the processing, not only of polymers, but also ceramics and metals, which need to be in powdered form [45]. However, these techniques are characterized by temperatures 
higher than $37^{\circ} \mathrm{C}$, which limit the direct incorporation of biological materials during the SLS/SLM processing. In addition, the mechanical properties of the final construct, its surface accuracy, and the control of the porous interconnected architecture may be affected by the material properties and by the parameters of the process [34]. Based on the same fabrication process of SLM, electron beam melting (EBM) differs from the previous technique for the use of an electron beam as a power source instead of a laser beam. In particular, EBM is preferable for the production of metallic constructs [34].

\section{Stereolithography}

Stereolithography (SLA) is a resin-based DLW technique based on the phenomenon of single photon absorption [34]. This technique involves the use of a continuous wave laser at the ultraviolet wavelength with relatively low energy to promote the polymerization of a photosensitive resin [37,42]. The UV light interacts with photoinitiator molecules inside the resin and the presence of the chain precursor in the same resin allows the release of free radicals, initiating the polymerization. Resins containing acrylate, epoxy, urethane acrylate, or vinyl ether functional groups are typically used [46]. Following the computer-aided designed geometry, the UV laser moves in 2-D over a reservoir containing the resin. The polymerization occurs a few $\mu \mathrm{m}$ below the surface, in the regions of the laser-resin interaction. The fabrication of the final 3-D construct happens layer by layer, relying on the down motion of the polymerized structure within the resin vat, after the selective polymerization of a given layer, which will be recoated with unpolymerized resin [7,32]. The displacement is equal to the thickness of the last polymerized layer, and the depth of penetration of the UV light allows the adhesion between layers. After fabrication, the final construct has to be placed in a developing solution to remove the unpolymerized resin, but some monomers of liquid resin can still be trapped within the structure, inducing toxicity. To overcome this issue, a post curing step is necessary, which consists in exposing the 3-D construct to high-intensity UV light for up to $2 \mathrm{~h}$ in order to polymerize the whole material, reducing its toxicity and increasing its hardness [37,42]. In the past years, SLA was the most used laser-based AM technique thanks to the low cost of the equipment and the relatively high processing speed due to the use of a continuous laser at low energies [34,37]. The spatial resolution achieved by SLA processes was limited by the diameter of the laser beam $(\sim 250 \mu \mathrm{m})$, but recent improvements in most commercial systems enable the production of scaffolds with a resolution greater than $50 \mu \mathrm{m}$ (up to $1 \mu \mathrm{m}$ ), and with well-interconnected and regular pores [37,41]. Moreover, SLA techniques avoid the use of high processing temperatures, allowing the incorporation of biological material within the structures during the fabrication process. In this case, the effect of laser energy, the toxicity of the photoinitiators, and the DNA damage induced by UV light have to be evaluated and could be a concern. To overcome these problems, visible light-based SLA are currently being investigated. SLA techniques show some limitations regarding the material selection due to the high thermal coefficient of expansion of SLA-compatible resin and the possibility of distortion and shrinkage of SLA-processed materials [33,37].

\section{Two Photon Polymerization}

Two photon polymerization (2PP) is a resin-based technique of DLW that, in a similar way to SLA, promotes the curing of a photosensitive resin, inducing chemical reactions between chain precursor and photoinitiator molecules, thanks to the excitation of the latter [47]. Differently from SLA, which is based on a single photon absorption, 2PP techniques rely on the near simultaneous absorption of two photons to excite photoinitiator molecules; this electronic excitation corresponds, in terms of energy, to the excitation achieved by a single photon, which possesses a much higher energy [48]. 2PP uses focused near-infrared (NIR) femtosecond laser pulses (with a wavelength of $\sim 800 \mu \mathrm{m}$ ) to induce the photopolymerization that occurs in regions where the energy exceeds the photoinitiator excitation threshold. The two photon absorption phenomenon shows a non-linear laser-material interaction due to a material response proportional to the square of the photon intensity; in this way, the reaction is greatly enhanced at the focal point, allowing feature sizes below the diffraction limit of the applied light. 
Thanks to that, 2PP can achieve a sub-100-nm spatial resolution, much higher than that of the other DLW techniques $[42,49,50]$. In addition to the use of a femtosecond laser, a 2PP system relies on the use of a high numerical aperture microscope objective in order to focus the laser beam and scale the feature sizes on Galvano mirrors that guide a translational platform to scan the beam in the $X$ and $Y$ directions, and on a piezoelectric system in order to shift the plane of resin or the objective holder in the $\mathrm{Z}$ direction. 2PP-compatible resin has to be UV curable and the advantage is that many materials, commonly used in 2PP, are transparent to NIR-wavelength light, making materials processed in 2PP widely available and inexpensive [37]. Moreover, the process can be set up in a conventional environment that does not require specialized equipment or cleanroom facilities [51]. The main advantage of 2PP technology remains the higher resolution achieved, down to the subcellular-length scale, with the possibility to fabricate a 3-D structure with a large range of features sizes, allowing, at the same time, minimization in processing time and costs. However, the restrictions due to the objective's working distance could limit the 2PP processes in terms of scalability compared to single photon absorption techniques (e.g., SLA) [42].

Two more DLW techniques exist in addition to the laser-based approaches previously described, but they fall outside the aim of this review as they are destructive techniques, and not AM approaches. Both involve the use of the laser ablation phenomenon and they are the laser machining technique based on the removal of a small amount of material from the bulk, and the matrix-assisted pulsed-laser evaporation (MAPLE) technique in which the material is transferred from a coated ribbon to a substrate [37].

\subsection{Deposition-Based Approaches}

Deposition-based approaches rely on the local and direct deposition of the material [7]. The solidification of the final 3-D construct occurs during or immediately after the material's deposition. These approaches can be classified in extrusion-based (e.g., fuse deposition modelling) and droplet-based techniques (multijet printing) on the base of the principle of operation $[7,52]$.

\subsubsection{Extrusion-Based Techniques: Fuse Deposition Modelling}

Extrusion-based techniques allow the building of a 3-D construct, which relies on the extrusion of the processing material in a continuous flow. The advantage in using this kind of approach is that the processes involved are mechanically simple and inexpensive [34]. The most common and accessible extrusion-based technique is fuse deposition modelling (FDM) due to the low costs of production and the easy principle of fabrication [53]. FDM could process any material, which can be in a filament form, and is based on the heating of thermoplastic polymers over their temperature of melting; the extrusion head moves in the $\mathrm{Z}$ direction, extruding the processing material as filament in a layer-by-layer fabrication thanks to its computer-controlled locations of deposition and its solidification upon cooling [7]. Despite the wide range of FDM-compatible thermoplastic polymers, the need to apply high temperatures to melt the polymers' filaments is an impediment to the direct encapsulation of biological materials during the process [7,32]. Even so, the change in the material's properties leads to a need to recalibrate all the setting parameters. The spatial resolution achieved is $\sim 250 \mu \mathrm{m}$, which limits the dimensional accuracy of the FDM-fabricated parts. However, this reduced resolution is compensated by the relatively high processing speed and by the lack of a need for toxic solvents as the binding between each layer occurs through thermal heating [32,41]. To overcome the restrictions in the input material properties, precision extruding deposition (PED) techniques could be taken into consideration. Differently from the FDM process, the PED system does not require filament preparation and the processing material is provided to the system in a powder form, subsequently liquified, and finally extruded though a nozzle. Moreover, in order to have the possibility to fabricate high-density metallic and ceramic parts, useful, for example, for the manufacturing of porous scaffolds for bone tissue regeneration, multiphase jet solidification (MJS) is an alternative to the FDM technique [34]. 


\subsubsection{Droplet-Based Techniques: Multijet Printing}

Droplet-based techniques allow the production of the final structure relying on the deposition of liquid material in droplet form instead of continuous flow as in extrusion-based ones [35,54]. Material solidification occurs after its deposition and could take place via cooling (crystallization), chemical changes (cross-linking), or solvent evaporation [35]. The most common droplet-based approach is multijet printing (MJP), which is based on the use of several heads placed on a jetting head, which, moving in the $X$ and $Y$ direction, deposits tiny droplets of UV-curable resin, promoting material layer formation on the build tray. Along the jetting head there are some UV bulbs that, after each layer is built, harden the deposited material and, shifting down the tray in the $\mathrm{Z}$ direction, allow the deposition of the next layer [55]. Control of the rheology, meaning the control of the viscoelastic flow behavior of the printing materials, is a crucial aspect of jetting techniques; the behavior of droplets and the liquid jet is affected by the physical properties of the chosen material, resulting in a restriction on jet-compatible materials, raising their cost. For these reasons, MJP is more suitable for large-scale production $[34,35]$. On the other hand, MJP has the great advantage of achieving a spatial resolution comparable to that of laser-based systems [34].

\subsection{3-D Bioprinting Techniques}

Recently, some deposition-based AM technologies have been developed for the fabrication of cell-laden biomaterials grounded on the direct encapsulation of biological materials, such as living cells and active molecules into formed 3-D constructs [7,56]. This kind of application has encouraged the evolution of the so-called bioprinting techniques.

Three-dimensional bioprinting techniques are based on the direct encapsulation of biological material during the fabrication process, giving rise to cell-laden biomaterials [33]. The most suitable materials used in bioprinting approaches are hydrogels, thanks to their ability to mimic the ECM and to provide a proper environment for cells, facilitating their migration, proliferation, and differentiation $[7,56,57]$. The use of hydrogels to carry cells and/or bioactive molecules defines them as "bio-inks" (hydrogels combined with biological materials) and involves the need to fulfil specific requirements regarding their rheology, in terms of viscoelastic properties, such as viscosity, and post-curing behavior, according to the proper bioprinting technique, to fabricate functional 3-D constructs [56,58]. When the final construct has been printed, processed, and the cells are alive within, it must achieve appropriate mechanical, physical, and biological properties. The main limitation of hydrogel-based AM technologies is the low mechanical properties, leading to difficulties in the fabrication of larger stiff structures $[7,59,60]$. The three most common 3-D bioprinting techniques are inkjet bioprinting, direct ink writing, and laser-assisted bioprinting, which differ for the deposition technique.

\subsubsection{Inkjet Bioprinting}

Inkjet bioprinting is a non-contact technique in which droplets of bio-ink are dispensed through a small orifice and precisely positioned on a substrate or a collective platform according to digital instructions [33,53]. Inkjet bioprinters differ for the physical mechanism of dispensing, which can be thermal, piezoelectric, or pneumatic microvalve based. The thermal mechanism relies on heating of the printhead generating the pulse that promotes the ejection of small vaporized bubbles. The localized heating in a thermal printer lasts for a very short time, but it can still cause a stressful condition for the deposited cells $[56,61]$. In the piezoelectric printer, a piezoelectric actuator generates an acoustic wave, which mechanically breaks the bio-ink into small droplets, forcing their ejection from the nozzle due to a transient pressure [56]. The pneumatic microvalve-based printer regulates the bio-ink ejection through a constant pneumatic pressure [21]. Inkjet bioprinting techniques are able to achieve a spatial resolution between 300 and $50 \mu \mathrm{m}$, and moreover, the quality of the printing may be affected by cellular aggregation within the hydrogel, which can induce changes in droplet formation and trajectory [62]. Moreover, one of the main restrictions of these techniques is the low upper limit of viscosity for the 
ink involved, hindering the processing of high viscous material and the building up of 3-D constructs and overhanging structures $[56,63,64]$. For this reason, inkjet bioprinting is mainly used for small scaffold production, with the capability to print a single cell per droplet [21,33]. The use of printheads with multiple nozzles has been investigated in order to increase the processing speed and allow the production of larger-scale constructs [65]. However, the small droplet size and the limitations in the viscoelastic properties of the materials involved, such as the low mechanical properties of the bio-ink, make the application of this technology challenging for larger-sized productions. On the other hand, inkjet bioprinting's flexibility to print multiple bio-inks makes possible the production of complex multiphase tissues [21,33].

\subsubsection{Direct Ink Writing}

Direct ink writing (DIW) is an extrusion approach, which implicates filament printing instead of droplets. It is based on the bio-ink extrusion through a printhead driven by piston, screw, or pneumatic pressure mechanisms in order to build up 3-D structures $[8,33,66]$. Piston-driven and screw-driven extrusion mechanisms are mechanical-based systems, which can induce cell apoptotic effects due to the pressure drops generated at the nozzle [67]. Pneumatic-based extrusion mechanisms are more suitable for work with highly viscous inks, as they are the only ones able to maintain a filamentous structure after deposition. Even so, mechanical-based systems promote more direct control over the ink flow and more spatial control on the ink ejection [67]. The high speed of fabrication and the ability to print at very high cellular densities within the inks are the main advantages of DIW techniques. DIW also allows control over the deposition and distribution of cells within the inks, and an excellent structural integrity due to a continuous deposition of the bio-ink [8,68]. For all these reasons, the application of DIW technology for scaffold fabrication is of great relevance, despite a spatial resolution of $\sim 200 \mu \mathrm{m}$, which is lower compered to inkjet and laser-assisted bioprinting [21,33]. One of the most common extrusion techniques able to produce polymeric non-woven fibers is electrospinning, which, allowing the possibility to incorporate biological compounds within processing materials, is able to fabricate cell-laden structures, with hydrogel based becoming a DIW technique [7]. Direct writing electrospinning (DWE) relies on the application of a high electric field to create an electrically charged jet of polymer, which is ejected from the nozzle of the Taylor cone and travels toward the collecting plate [67]. DWE enables the fabrication of 3-D structures, single-fiber or multi-fiber, with a well-controlled geometry [69]. Despite this, there is a need to carefully consider the rheology of the extruded material and the desired features of the final scaffold, as the main limitation of this technique is the difficulty to set the process parameters $[7,67]$.

\subsubsection{Laser-Assisted Bioprinting}

Laser-assisted bioprinting (LAB) is a droplet-based and scaffold-free technique based on the use of a laser as the energy source to deposit biomaterials on a substrate [33,70]. LAB consists in a pulsating laser, a donor slide coated with the target biomaterial to support it, and a natural or synthetic receiver slide to collect and support the printed material. The donor slide is also coated with a thin gold/titanium layer, which, via laser induction, promotes a vaporization effect on the biological materials, propelling it onto the receiver slide in droplet form. To maintain cellular viability, the receiver slide is covered by a biopolymer or cell culture medium [71,72]. The precursor biomaterial used is hydrogel and the nozzle-free approach enables the use, not only of mid-range-viscosity bio-ink, but also of high-viscosity ones [66]. Moreover, the main advantage of LAB approaches is the possibility to achieve high resolutions greater than $20 \mu \mathrm{m}$, maintaining a high activity for encapsulated cells, and the ability to control the features of the ink droplets and their delivery properties [33,71]. Even so, the resolution and the final mechanical integrity of the construct may be affected by the hydrogels' viscoelastic properties and the layer thickness of the precursor biomaterial, by the energy of the laser pulse, and by the organization of the desirable structure $[33,71,73]$. 
Future developments in 3-D bioprinting techniques require the combination of different approaches in order to provide the accuracy in cell placement and resolution of inkjet bioprinting and LAB, and the processing speed and greater mechanical integrity of DIW.

\section{Geometries}

\subsection{Specific Geometry in Scaffold Design}

Depending on the different manufacturing techniques, scaffolds can present different degrees of stiffness and different geometries [74]. In particular, scaffolds must be designed to reproduce the stiffness of the native tissue to regenerate and transplant, and they must present a resolution suitable at the cellular scale [75]. The nano or micro-topography and the specific geometry of different biomaterials induce, at the single cell level, different cytoskeletal tensional states, given by the intracellular actomyosin contractility and by the reaction forces exerted by the surrounding substrate [76]. Indeed, different external stimuli and different geometries can influence specific cellular responses. It is thus necessary to fabricate a scaffold, which mimics the tissue's physiological environment. The traction forces exerted by the cell depend on the specific scaffolding substrate and produce a different response inside the cell nucleus, resulting in an altered gene expression [77]. Indeed, the study of mechanotransduction allows the understanding of how cells respond to external stimuli $[78,79]$.

Several studies have been conducted to investigate the influence of scaffold design parameters on the cell's mechanical and biological responses [74,80-85]. Depending on the specific tissue regeneration, the biomaterial features and geometries of the scaffold were optimized, suggesting sophisticated micro-architectures for unit cell scaffolds [86]. Not only the Young's modulus of the biomaterials, which represents the index of their stiffness, must be considered to design the scaffold but also the porosity, and the pore size and shape are fundamental parameters to optimize the scaffold performance $[87,88]$.

\subsection{Techniques Employed for the Fabrication of Rigid Scaffolds}

SLM, SLA, 3-D bioprinting, and fuse deposition modelling, described in the previous paragraphs, are the most common techniques used for the fabrication of rigid scaffolds [89,90]. In particular, scaffolds with a high Young's modulus are used for bone regeneration, in order to simulate the rigidity of the bone in vivo [91]. Indeed, these techniques have a specific and controlled geometry that allows for a higher resolution. In the field of bone regeneration, many researchers focused their attention on the geometries of the scaffolds' pores. Specifically, important matrix parameters are the pores' size and shape, and their interconnectivity [92,93]. With the support of algorithms and computer-based models, it was possible to identify the optimal range of pore dimension between 500 and $1000 \mu \mathrm{m}$ and specific tetrahedral and octahedral geometries fabricated with the SLM technique [94]. In addition, Stoppato et al. demonstrated that, even if a specific geometry is required, a random distribution of the pores seemed to be more suitable for a bone tissue regeneration application, with osteoblasts producing a collagen architecture similar to the natural matrix [95]. Moreover, the pores' distribution and interconnectivity strongly influence the cells' ability to proliferate and differentiate [96].

\subsection{Techniques Employed for the Fabrication of Soft Scaffolds}

As previously described, most of the scaffolds with a higher stiffness are compatible with bone regeneration but of great interest are also the scaffolds for the regeneration of soft tissues. The two most common applications of soft scaffolds are muscle and nerve regeneration, where the architecture and the spatial organization of the entire scaffold are necessary. Different fabrication techniques, such as bioprinting and in particular inkjet printing, are suitable for soft materials and specifically for the regeneration of soft tissue [97,98]. In particular, in muscle tissue where there is a strong structure-function relationship, the ability to control the geometry for tissue implantation is essential [99]. The necessary parameters to consider are represented by surface roughness, pores, grooves, walls, and pillars, which can be used to guide cell behavior in terms of adhesion, alignment, 
and motility [100]. Indeed, the contact guidance for cell directionality and the advanced manufacturing microfabrication permit polymeric micro-structured substrates to be obtained that influence myoblast and myotube formations [100]. Furthermore, tridimensional scaffolds with a micropatterned array can mimic the aligned architecture of the natural skeletal muscle tissue, enhancing tissue regeneration [101].

In addition to polymer scaffolds, naturally derived hydrogels have several properties that guarantee the functionality of the muscle tissues. For smooth muscle cell differentiation, it is also possible to consider micropatterned biomaterial-based hydrogel platforms, where mesenchymal stem cells can be induced to differentiate, following precise patterns [102]. Moreover, other studies involved different approaches that utilize photolithographic patterning of hydrogels, enabling a relatively fast layer-by-layer assembly of cells with a controllable geometry and size [103,104].

The same fabrication techniques used for soft scaffolds and hydrogels can be relevant for the fabrication of structures aimed at enhancing the features of the neural tissue. In this case, the structure of neural scaffolds is extremely important for the efficacy and has significantly advanced in recent years [105]. To this end, innovative scaffolds, such as multichannel scaffolds and grooved substrates, have been developed in order to enhance the directionality of growing neuronal processes [106,107]. In this case, the dimension of the guidelines is precise and governs the elongation of the cells with an anisotropic tension state [108].

\subsection{Structure to Function: Importance of Geometry in Enhancing Cellular Features}

The concept that rigid scaffolds are necessary for rigid tissue regeneration and soft scaffolds for soft tissues can be partially overcame when trying to enhance specific cellular features. This is extremely relevant for stem cells' proliferation and stemness maintenance where the precise and controlled geometry of the scaffold is necessary [109]. The difference in this case is the clinical translation, more focused on the amelioration of stem cells features as therapeutic agents rather than whole tissue re-implantation. To this end, an innovative study inspired by the natural stem cell niche has led to the development of a new stem cell culture system named "Nichoid". This engineered scaffold is fabricated by 2PP and it is composed of a three-dimensional succession of grids and columns able to create perfectly defined pores at the micrometric scale, ensuring the optical accessibility. Cells expanded inside the Nichoid are subjected to isotropic mechanical stimuli driven by the cytoskeleton [110-113]. Typically, if the traction forces have a similar magnitude at varying orientations (i.e., isotropic cytoskeletal tension), the cellular nucleus tends to maintain a roundish morphology [114]. For this reason, when cells are grown inside the Nichoid they tend to maintain a round nucleus, similarly to the stem cells' physiological morphology [77].

Conversely, in some cases, anisotropic stimuli are required for a specific commitment differentiation. Indeed, the benefit of scaffold anisotropy was evident with human-induced pluripotent stem cell-derived cardiomyocytes, where parallel-aligned polymer scaffolds can provide contact guidance to cells to reorganize cellular orientation and differentiation [115]. Moreover, Zhang and colleagues applied biomechanical and biochemical stimuli to mesenchymal stem cells seeded into a biomimetic scaffold to induce the differentiation of fibrochondrocytes, resulting in physiological anisotropy in the engineered meniscus [116].

\subsection{Development of Optimal Scaffolds for the Neural Tissue: A Role for Geometry and Stiffness}

The brain is one of the most complex organs to cure and mimic, and in this sense advances in scaffolds development could be of great relevance in order to enhance specific neural features. Indeed, nano-structured scaffolds are a promising strategy to promote axon regeneration, needed for the therapy of neurodegenerative diseases [117]. Moreover, the scaffold's fibers ensure the directionality of neurite outgrowth and the alignment of neural cells, as observed by cellular elongation and neurite differentiation when these are used [118]. Indeed, Friecke, in 2011, developed different nanostructured patterns by microcontact printing using laminin/poly-l-lysine (PLL). These 3-D structures were investigated for their impact on neurite growth and axon guidance in embryonic 
rat cortical neurons [119]. Using the same technique and the same materials, another interesting study developed by Jang et al. analyzed 10 different types of micro polygons, ultimately observing that the geometry of the scaffold strongly influences the development of a cultured neuron [120]. In 2017, Kim et al. investigated a different technique, termed electrospinning, in order to develop a 3-D connected artificial neuronal network within a nanofiber-microbead-based porous scaffold. This inspiring scaffold allowed substantial neurite outgrowth in a vertical direction [121].

Another feature that needs to be enhanced for neural tissue mimicking and therapy is neural differentiation. Not only the geometry of the scaffold but also its stiffness modulation could influence this process. Indeed, physiologically, neuronal growth and neural network activity are strongly influenced by the mechanical properties of the surrounding ECM [122]. Controlling the scaffold's features in order to resemble the ECM is crucial for enhanced neural differentiation. One research work reports that, specifically, neuronal differentiation was favored in the softest surfaces with a Young Modulus of $1 \mathrm{kPa}$, whilst oligodendrocyte differentiation was enhanced in stiffer scaffolds $(>7 \mathrm{kPa})$, and lastly astrocyte differentiation was only observed on $<1$ and $3.5 \mathrm{kPa}$ surfaces [123]. Indeed, Her et al. showed that mesenchymal stem cells can differentiate into the neuronal lineage in a substrate that present a Young modulus of $1 \mathrm{kPa}$, while they transformed into glial cells when this parameter is $10 \mathrm{kPa}$ [124]. Moreover, a recent work has shown that the physicochemical properties of the alginate/collagen blend could resemble the ECM microenvironment, influencing neuronal-specific gene expression [125]. In particular, it was shown that oligodendrocyte differentiation and maturation in vitro is enhanced by substrates within the reported range of stiffness of the brain [126]. Finally, Saha et al. developed a synthetic interpenetrating polymer network, which creates a highly mechanically and chemically stimulating environment for multipotent neural stem cells to control their proliferation and differentiation [127].

\section{Scaffolds for Neural Diseases' Modeling}

The brain is difficult to access, susceptible to damage, and complex, making it one of the hardest organs to be studied. This poor understanding of the brain leads to a lack of effective treatments for several neurodegenerative diseases, such as Alzheimer's disease (AD), Parkinson's disease (PD), and amyotrophic lateral sclerosis (ALS), but also for acute or traumatic Central Nervous System injuries, such as acute ischemic stroke (AIS) and spinal cord injury (SCI). New methods for a realistic culture of neural cells are needed, and in particular in vitro 3-D cultures represent a promising tool to reconstruct the complex structure and function of the human brain [128]. Traditional monolayer cell cultures cannot mimic tissue architecture, mechanical and biochemical cues, and cell-cell communication. On the contrary, 3-D cell culture systems aim to mimic the living tissue, providing a more physiologically relevant environment [129]. Many natural or synthetic materials can be used to engineer the neural tissue in a 3-D in vitro model, but also functionalization with specific peptides can improve the adhesion, proliferation, and differentiation of neural cells $[130,131]$. Specifically, two innovative approaches that can be used for neural diseases' modeling are decellularized scaffolds and hydrogel-based biomaterials.

\subsection{Decellularized Scaffolds}

An interesting approach to create highly biocompatible bio-inks is decellularization, which consists in removing the cellular content from animal and human-derived tissues. This method allows the production of tissue-specific ECM scaffolds that can more accurately recapitulate the native matrix [132]. These bio-inks have an enormous potential for in vitro modeling of neurodegenerative diseases phenotypes and for evaluating the tissues' responses to new potential drugs [132]. A potential issue is represented by the complexity of the brain tissue, such as the diverse conditions in terms of the growth factor content. To overcome this, Reginensi and colleagues evaluated for the first time decellularized bio-inks from different sections of the brain (i.e., cortex, cerebellum, and remaining areas) using both mechanical and chemical decellularization protocols [133]. Intriguingly, they found that the chemical method (mixture of different enzymes) promotes greater differentiation, probably 
because it allowed the conservation of the biochemical components of the cerebral ECM. Moreover, the authors show differences in neuronal maturation depending on the region of the brain used to produce the scaffolds [133]. One of the main advantages of decellularized scaffolds is the possibility to chemically modify them to obtain better features. To this end, Beachley and colleagues developed a decellularized brain tissue scaffold crosslinked with glycosaminoglycans, to facilitate ECM hydrogel formation without a disruptive enzymatic digestion process [134]. Moreover, they proved that using the ECM from different tissues at various concentrations allowed the gelation kinetics and mechanical properties to be easily tuned to offer the possibility of numerous in vivo and in vitro applications with different property requirements [134]. Decellularized scaffolds can also help the differentiation of glial cells. Cho and colleagues utilized decellularized human brain tissue and found an enhancement of the differentiation of induced Pluripotent Stem Cells (iPSCs) myelin-expressing oligodendrocytes, which improved the electrophysiological properties of induced neural cells [135]. Decellularized scaffolds could also offer new opportunities for therapeutic applications in regenerative medicine. For example, Lin and colleagues used brain-derived decellularized scaffold added with basic fibroblast growth factor (bFGF), which is studied as a potential agent for PD. They found that the presence of bFGF not only enhanced the viability of PD model cells but also improved the behavioral recovery and positive expressions of neurotrophic proteins in PD rats [136]. The therapeutic potential of decellularized bio-inks was also evaluated by Tukmachev and colleagues, who assessed the effects of both porcine spinal cord and porcine urinary bladder decellularized injectable hydrogels in an in vivo model of acute SCI. They found that both types of hydrogels integrated into the lesion, stimulating neovascularization and axonal ingrowth into the lesion. On the other hand, they found a rapid degradation of the hydrogel [137]. In conclusion, decellularized scaffolds represent an interesting innovative technique for the generation of a new neurodegenerative model and for the development of new therapeutic approaches, but further studies must be conducted in order to resolve the actual issues.

\subsection{Hydrogel-Based Biomaterials}

One of the most relevant groups of biomaterials that can be chosen are hydrogels because of their high biocompatibility, their chemical features, and their similarity to the ECM [138]. One of the first attempts to generate a layered brain-like structure is represented by the work of Lozano and colleagues [139]. The group combined mouse primary cortical neurons with a bio-ink composed of gellan gum functionalized with the arginine-glycine-aspartic acid (RDG) peptide. They demonstrated that the bio-ink strongly supported the neural proliferation and cell-cell communication [139]. The ability to form discrete multiple layers opened the opportunity to reproduce accurate 3-D human brain models [139]. Indeed, another important parameter to evaluate the best approach in modeling neurodegenerative diseases is the specific cell type. For preliminary studies, such as the biocompatibility of the hydrogel, immortalized cell lines are used, such as rat pheochromocytoma cell lines (PC12) [140] and the human neuroblastoma cell line (SH-SY5Y) [141]. Such models can help investigate the effects on the maturation/differentiation of composite hydrogels or other biomaterials. For example, some studies were conducted on conductive hydrogels [142-144], nanofibrous scaffolds [145-147], and self-assembling peptide scaffolds [148,149]. Although such cell lines are important for preliminary investigations, to obtain a realistic in vitro model, it is essential to use stem cell-derived mature neurons. In the last years, the possibility to reprogram somatic cells into iPSCs allowed patient-derived neural cells to be obtained, opening new possibilities in the field of tissue engineering. The use of iPSCs with hydrogels can offer some advantages. For example, Zhang and colleagues found that a hyaluronic acid-based hydrogel accelerates the maturation of iPSCs into neural progenitor cells, because of the similarity with the brain tissue [150]. Although iPSCs were 3-D bioprinted and then differentiated into the hydrogel, some evidence suggests that is better to directly bioprint iPSC-derived neural stem cells (NSCs) [151]. This specific fabrication technique was used, and many phenotypic aspects were investigated, such as the analysis of neurite extension and neural maturation on polyethylene glycol [152] or 3-D gelatin methacrylate [153] hydrogels. Moreover, iPSC-derived mature neurons 
were bioprinted and cultivated on hydrogel scaffolds, and many read-outs were evaluated, such as the expression of integrins, the formation of a complex network, and the expression of synaptophysin along the neurites [125]. iPSCs can also be differentiated into glial cells, which proved to play a pivotal role in the pathogenesis of neurological disorders. For example, in 2020, Nazari and colleagues differentiated iPSCs into oligodendrocytes in a fibrin-based hydrogel, demonstrating a better proliferation in the 3-D culture system with respect to monolayer culture [154]. In particular, the results reported demonstrated that fibrin hydrogels provide a metabolically active microenvironment for cells, mimicking specific features of native tissue.

All these studies provide a strong evidence that hydrogel-based scaffolds can mimic in a very realistic way the neural ECM, opening new perspectives for the study of neurological disorders and for the development of new therapeutic approaches.

\section{The Role of Scaffolds in Developing Regenerative Therapies for Neurodegenerative Diseases}

Amongst all the organs, the human brain possibly represents the biggest challenge in terms of the modelling and development of therapeutic strategies. Its structural complexity and the inability to retrieve samples without highly invasive, and often unfeasible, approaches represent the major limitation in the study of physiological and pathological brain activity. The brain's inability to regenerate also implies that damages are often irreversible, and, so far, no cure for neurodegeneration has been found. For this reason, there is an unmet need for new strategies aiming at modeling and curing neurodegenerative diseases. The use of scaffolds becomes of great relevance in this field, as they can be used to mimic the brain's morphology and function, to improve cellular growth for transplantation means, to improve drug delivery, and even to be directly transplanted at the lesion site.

As mentioned above, the main unmet clinical need in neurodegenerative diseases is the lack of successful replacement therapy for damaged brain tissue. Although it is worth looking at recent advances made in specific diseases, some common patterns can be highlighted. Indeed, in all cases, it is possible to discriminate between the transplantation of empty scaffolds, of scaffolds carrying specific therapeutic agents, of cell-loaded scaffolds, or scaffolds combining cells and molecules. The use of scaffolds allowed significant advances in disease modeling, as explained in the previous paragraph, and when focusing on diseases therapy, most research is currently focused on pre-clinical studies. Indeed, although there is a great potentiality for scaffolds' use, it is of course firstly necessary to evaluate the safety and efficacy of each scaffold in pre-clinical models [155-166]. Indeed, a lack of toxicity and an improvement in diseases' hallmarks are necessary aims that need to be fulfilled before moving on to clinical practice. Indeed, the implant of scaffolds in humans is currently limited, with one of the few examples being represented by in the Neuro-Spinal Scaffold (InVivo Therapeutics Corp.) for the treatment of SCI $[167,168]$. All these aspects are reported in Figure 3.

Similarly to disease modeling, the most promising and commonly used material in the treatment of these diseases is hydrogel for its increased bioavailability and characteristics, which mimic those of the ECM well. The most commonly used approach is the delivery in situ of pharmaceutical agents already known for their therapeutic potential in the specific disease. The use of scaffolds in this case improves the therapeutic efficacy as the contained agents are "protected" by the hydrogel and thus present a decreased degradation rate $[156,169]$. In a similar manner, cell-loaded scaffolds can bridge stem cell therapy with tissue engineering, improving the delivery of stem cells to the lesioned site [159-162]. Even if most of the first developed agents contained one therapeutic agent, combinatory approaches now aim to deliver both drugs and cells, or even different drugs contained in the same scaffold but released at different times after scaffold delivery [170]. This is a great advancement as often just one therapeutic agent is not enough to re-create the physiological situation that was present before the lesion began. In some cases, it is also possible to have a controlled release of the therapeutic agent, allowing its constant and prolonged delivery. Even so, more recent works are investigating the potentiality of different materials and structures, such as it is the case for electrospun polymers in PD [171,172]. 

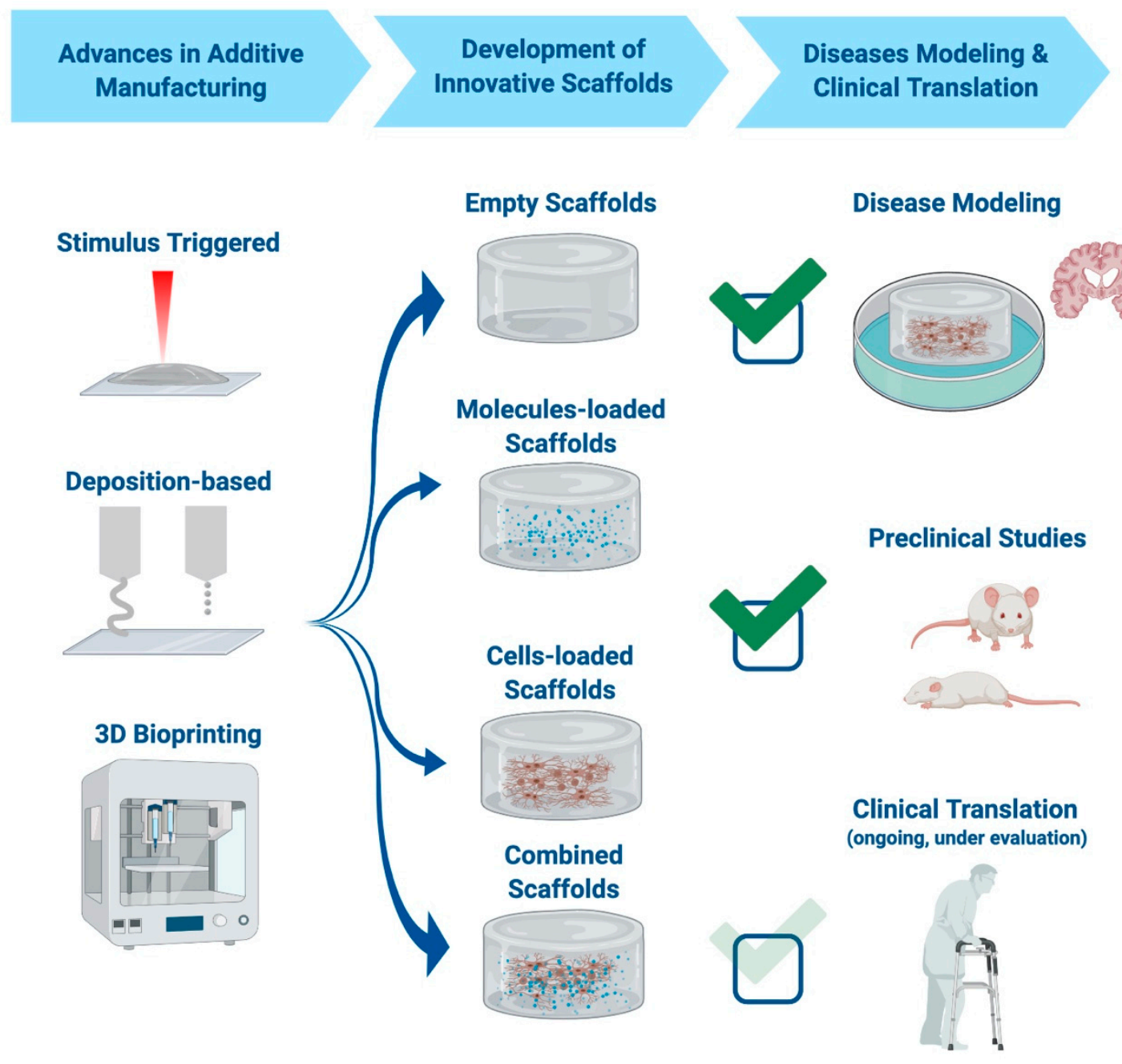

Figure 3. Use of additive manufacturing techniques in neurodegenerative diseases. Scaffolds can be either printed or bio printed, and embedded with molecules, cells, or even a combination of the two to increase their therapeutic efficiency. Recent advances in production technologies have shown a relevance for these techniques in disease modeling and preclinical models of neurodegenerative diseases. Current efforts are focusing on the development of safe and efficient strategies for human clinical translation. Made in (CBioRender-biorender.com.

\subsection{Alzheimer's Disease}

Alzheimer's disease (AD) is the main cause of dementia worldwide, characterized by a decline in cognitive functions and subsequent memory loss $[173,174]$. The two cellular hallmarks of the disease are the presence of extracellular amyloid plaques and intracellular neurofibrillary tangles (characterized by tau hyperphosphorylation) [175]. Even so, very little is known about the causes that lead to AD onset, and to this day, there is no curative therapy for the disease $[174,175]$. There is thus a need to evolve from current pharmacological strategies, which, for now, are only a symptomatic remedy $[174,176]$. A therapeutic advancement that is gaining more and more relevance this day is the use of scaffolds, advantageous for both drug delivery and for promoting stem cell delivery and survival in the hostile AD microenvironment [176]. In this context, hydrogels are of key importance for the delivery of therapeutic agents, in order to increase their bioavailability [156]. Examples include biodegradable microspheres loaded with huperzine A (a natural acetylcholinesterase inhibitor) [177], microemulsion loaded with tacrine [178,179], microspheres optimized to deliver Nerve Growth Factor (NGF) [180], poly(lactic-co-glycolic acid) (PLGA) nanoparticles loaded with estradiol or tempol [181,182], and hiolated chitosan hydrogels loaded with donepezil [183]. Innovative developments combine more therapeutic aspects, such as a novel peptide-based hydrogel, 
which contains a peptide that stabilizes the microtubules, associated to a neuroprotective action, and able to promote neurite outgrowth of neuron cells [184]. This hydrogel is also able to encapsulate curcumin and release it slowly, and although this hydrogel has not been tested yet in vivo, it could represent a promising therapeutic strategy [184]. Recently, a combinatory approach has also been tested, combining liposomes with hydrogels and delivering an active pharmaceutical ingredient, in order to improve bioavailability [185].

Furthermore, scaffolds can be combined with stem cell therapies to improve functional outcomes in AD [176]. An example of this is the scaffold made of RADARADARADARADA (RADA16) peptide combined with part of the laminin sequence, which when transplanted with NSCs in a rat model of AD protected cells against apoptosis and promoted neuronal differentiation, resulting in an improvement of behavioral outcomes [155].

\subsection{Parkinson's Disease}

Parkinson's disease (PD) is the second most common neurodegenerative disorder, characterized by the loss of dopaminergic neurons in the substantia nigra pars compacta (SNpc) [186] and the presence of alpha synuclein, which aggregates in toxic components termed Lewy bodies [187]. The first line of therapy for the treatment of PD is dopaminergic agonists (such as L-3,4-dihydroxyphenylalanine, L-DOPA, combined with other tested drugs), which only provide a symptomatic remedy and allow treatment for at least 5 years [188]. Other pharmacological agents and even stem cell therapy are being considered for the treatment of $\mathrm{PD}$, but a disease-modifying therapeutic agent has not yet been developed [189]. A number of works have investigated the potentiality of hydrogels in the delivery of therapeutic agents (both pharmacological and biologicals) in in vivo models of PD [156-158]. Indeed, the delivery of pharmacological agents, which have been proved effective in the attenuation of PD's symptoms, can be potentiated with hydrogels [156,169]. These scaffolds "protect" the delivered neurotrophic agents (e.g., Glial cell-derived neurotrophic factor GDNF, NGF) and promote a controlled and localized release, as it is possible to determine their decay. Examples include the development of systems aimed at improving the delivery of the therapeutic agent: A hydrogel-based system aimed at improving transdermal dopamine delivery [157] and a biodegradable polymer matrix releasing dopamine in the striatum of a hemi-parkinsonian animal model [190]. Systems have been developed for the administration of neurotrophic factors, already partially studied as treatment of the diseases, such as GDNF-loaded microspheres stereotaxically implanted in brain of PD-affected animals [158,191,192]. Hydrogels have also been used for the delivery of less canonical therapeutic agents, such as Tat-fused protein Heat Shock Protein 70 (Hsp70) [193], activin-B [194], or even the secretome of mesenchymal stem cells [195]. In comparison to canonical drug delivery, cell therapy is also a promising approach for PD therapy [196,197]. Indeed, another bioengineering application is the use of an innovative strategy to improve the efficiency of hydrogel in cellular transplantation and delivery through the addition of neurotrophic factors (such as BDNF), adhesion molecules, or a combined system of hydrogels and nanoparticles [198-204]. Hydrogels can also be used to ameliorate the differentiation of iPSCs to a dopaminergic phenotype, which could prove useful in drug screening and disease modelling [205].

Aside from hydrogels, very few studies investigated the potentiality of scaffolds in the therapy of neurodegenerative diseases. Carlson and colleagues developed three-dimensional microtopographic scaffolds using tunable electrospun microfibrous polymeric substrates that appear to promote in situ stem cell neuronal reprogramming, neural network establishment, and support neuronal engraftment into the brain. The authors aimed to develop a mini-neurocircuitry composed of excitatory dopaminergic neurons, which could have a profound impact in the amelioration of PD symptoms [171]. Another novel 3-D nanofiber scaffold has been developed using electrospun PAN, a pure carbon-based polymer, and Jeffamine ${ }^{\circledR}$ polymer-infused PAN. Both scaffolds are capable of promoting survival and proliferation of SH-SY5Y and U-87MG cells, and when these were incubated with PD-mimicking agents, cell survival inside the scaffold was increased with respect to 2-D culture conditions [172]. 


\subsection{Amyotrophic Lateral Sclerosis}

Amyotrophic lateral sclerosis (ALS) is the most prevalent motor neuron disease, characterized by the progressive loss of upper and lower motor neurons [206]. Life expectancy is 2-5 years after the first diagnosis, with death being caused in the majority of cases by muscle atrophy and paralysis, which becomes life threatening when respiratory muscles are involved [207]. Other than the canonical neuronal dysfunctions observed in neurodegenerative diseases (e.g., oxidative stress, protein aggregation, loss of synaptic activity), a strong contributor for the development of ALS pathogenesis is represented by astrocytes, which in the disease lack the ability to support neurons [208-210]. For this reason, and for the complex multi-cellular system present in ALS, 2-D cultures are not sufficient to recapitulate the disease course. Even so, a very limited number of 3-D scaffold-based therapies have been developed, and future studies should focus on their development in order to gain more in-depth insight in disease pathogenesis $[210,211]$.

Gingras and colleagues developed a 3-D tissue engineered model to study motor neuronal axonal migration and myelination. In this model, mouse spinal cord motor neurons were seeded on a collagen sponge populated with Schwann cells and fibroblasts. The model permitted study of the fundamental characteristics of motor neurons, such as neurite outgrowth and spontaneous myelination. Even if performed in healthy cells, the model could prove to be relatable and applicable for the study of the pathogenesis of motor neuron diseases [212]. The possibility of combining healthy and diseased cells (such as the ones that can be obtained from ALS patients) allows the identification of the effects of neuronal or astrocyte toxicity in ALS and to create more representative disease models [211]. Another aspect of ALS pathology that needs to be investigated is the muscles' role in the disease. A very interesting 3-D model was represented by primary muscle cultures obtained from human control subjects and ALS patients, embedded in a collagen gel. The model also allowed the study of gel contraction and the aim was to study in vitro the effect of muscle stretching on mRNA expression in diseased muscles cells $[213,214]$. The gold standard model that recapitulates all of the disease aspects observed in ALS would have to be a whole spinal cord organoid obtained from ALS patient-derived iPSCs [215]. Although this has not yet been developed, recent advances allowed the development of 3-D-engineered spinal cord models [216,217]. In particular, Bowser and Moore developed a combined microphysiological system, where spinal cord spheroids are fabricated using magnetic nanoparticles and then positioned in a 3-D hydrogel construct using magnetic bioprinting [217]. So far, no studies are present that have investigated scaffolds for the treatment of ALS. Even so, devices, such as the "syringe-injectable nano-scale electronic scaffolds", which can be used to monitor neural activity, stimulate tissues, and promote neuronal regeneration, could be of great relevance in the treatment of the disease [218]. Lastly, one work developed a technique for intrathecal transplantation of glial progenitor cell-loaded hydrogels through Magnetic Resonance Imaging (MRI)-guided delivery in a naturally occurring ALS-like disease in dogs. The procedure was found to be safe and the embedded cells were successfully placed [219].

\subsection{Acute Ischemic Stroke}

Acute ischemic stroke (AIS) is caused by a transient or permanent reduction in cerebral blood flow, generally caused by the occlusion of a cerebral artery, an embolus, or local thrombosis [220]. The consequences of AIS are hypoxia, an increase in radical oxygen species, and an excessive inflammatory response, which can lead to long-term consequences [220,221]. AIS leads to a loss of brain tissue, which is not regenerated, even if neurogenesis partially occurs, and this is due to the lack of structural support and the fact that the tissue undergoing injury creates a boundary to avoid damage expansion into the healthy tissue [222]. It is for this reason that bio-scaffolds could prove useful for the therapy of this disease, providing structural support [222,223]. The first evidence that supported the potentiality of scaffold use in AIS was determined after the transplantation of NSCs on polymeric scaffolds, with promising results [159-162]. Hydrogels improved the interaction between NSCs and the host tissue, through neuronal differentiation, re-formation of cortical tissue, increased 
connectivity, reduced inflammation, and reduced scarring [159]. Similar results were obtained when NSCs were transplanted with polymerized allylamine (ppAAm)-treated PLGA scaffolds [224] and xenogenic extracellular matrix bio-scaffolds [225]. Other types of cells, such as iPSCs [152,226] and bone marrow mesenchymal stem cells, can be transplanted together with other kinds of scaffolds (e.g., gel-like scaffold from plasma) [227]. Limitations with these approaches included the non-homogeneity of the scaffold and the need for vascularization [222,224,225]. Another scaffolding approach used for the treatment of AIS is 3-D bioprinting [228]. In the case of AIS, biomaterials can favor cellular integration and reduce the immune response [228-230].

Additionally, in this case, hydrogels can be used for the delivery of pharmacological agents, which proved beneficial for stroke, such as erythropoietin (EPO), a cytokine found to promote neurogenesis after AIS [223,231,232]; or vascular endothelial growth factor (VEGF), capable of inducing structural protection after AIS [233,234]; and brain-derived neurotrophic factor (BDNF) [235]. Hydrogels have also been developed for sustained delivery of cyclosporine $\mathrm{A}$, stimulating neurogenesis in the damaged tissue of rodent brains $[236,237]$. Combinatory approaches can also be used, such as the co-administration of EPO and epidermal growth factor (EGF) [238,239] or of VEGF and angiopoietin-1 [240]. In the case of AIS, hydrogels have also been combined with proteins, proving efficient in the treatment of the disease [223]. Specifically, they have been linked to genipin [241] and fibrin [242-245]. There is a need to develop a strategy to correctly implant hydrogels, and also in this case, as reported for ALS, an MRI-guided approach could be adopted $[225,246]$. It is very interesting to report that in the case of AIS, bio-scaffolds could also serve as a preventive tool, especially in cases where atherosclerotic plaques are already present and represent a strong risk factor for AIS insurgence [228]. Although no trials have yet been done, the combination of computational fluid dynamics based on patients' imaging and scaffolds with a patient-specific 3-D geometry could allow first the testing and then the implantation of devices able to correct the arterial flow [228].

\subsection{Spinal Cord Injury}

$\mathrm{SCI}$ is a devastating disease caused by high-energy trauma, which leads to severe neurological dysfunctions $[247,248]$. Patients suffer from partial or complete limb paralysis, associated with sensory dysfunction, urinary incontinence, or gastrointestinal dysfunctions $[247,248]$. To this day, there is no curative therapy, and treatments are aimed at reducing secondary degeneration with high-dose corticosteroids, surgical stabilization, and decompression $[249,250]$. It is especially during surgical stabilization that scaffolds could prove to be efficient, maybe improving current lines of therapy. The concept of a solid matrix providing support in SCI has already been tested [251,252] and it is worth focusing on both the potentiality of scaffolds alone and that of scaffolds combined with therapeutic agents (stem cells, drugs, growth factors, etc.). In the initial approach, synthetic scaffolds (e.g., physical chitosan microhydrogels) were used to bridge the extremities of damaged spinal cords to promote regeneration and connectivity [253-255]. More recently, they were implemented with drugs, growth factors, and even stem cells in order to obtain a controlled release of drugs, stimulation of endogenous regeneration, and local secretion of neurotrophic factors and stem cell delivery [163-166]. Scaffolds that can be used for SCI were illustrated in depth by Zhang and colleagues and include: Biodegradable synthetic polymer scaffolds (PCL, PLA, PLGA, PEG), non-biodegradable synthetic polymer scaffolds (PHEMA, PHPMA, PAN/PVC, conductive polymers), and natural polymer scaffolds (collagen, chitosan, alginate, fibrin) [256]. An interesting and promising technology is represented by graphene oxide (GO) 3-D nano-structured scaffolds, able to stimulate neuronal differentiation thanks to unique electro-physico-chemical properties [257-260]. To this end, a key player in providing structural support could also be the physiological tissue, such as adipose tissue, which has proved promising in the treatment of the disease [261,262]. Studies showed that the beneficial effects were given not only by the structural support but also by the fact that mesenchymal stem cells present inside the adipose tissue promoted regeneration and recovery of function, and reduced the inflammatory response [261,262]. 
Amongst the neuroprotective factors incorporated in hydrogels, promising results have been obtained with the delivery of neurotrophin-3 [263-265], nerve growth factor [266], BDNF [267], and neuregulin [268]. One of the most innovative research works in this field required a complex combinatorial system of growth factors and bio-scaffolds. It was based on a two-step protocol, with different factors being modulated before and after the lesion, in order to allow for axonal re-growth. The protocol began with a time-dependent administration of adeno-associated viral vectors to reactivate neuroregeneration (through downregulation of phosphatase and tensin homologue; upregulation of osteopontin, insulin-like growth factor 1, and ciliary-derived neurotrophic factor). After SCI was induced, the protocol required the injection of biomaterials (made of diblock copolypeptide hydrogels) delivering fibroblast growth factor 2, EGF, glial cell-derived neurotrophic factor (GDNF), and integrin-blocking antibody [170]. Other than compounds, bio-scaffolds can also in this case be used to deliver stem cells, most frequently human mesenchymal stem cells, widely used in the treatment of the disease [269-271], but scaffolds complexed with NPCs have also been developed [166,272,273]. It is worth mentioning that in the case of SCI, biomaterials (in particular the Neuro-Spinal Scaffold InVivo Therapeutics Corp.) have also been used in clinical practice $[167,168]$. The trial has completed recruitment and is currently in the follow-up phase (NCT02138110), but the case of a patient who underwent surgery has been published, with improvements in neurological function and no procedural complications [168].

The results of the recent advances reported above are summarized in Table 2. These include scaffolds fabricated with additive manufacturing techniques along with innovative discoveries aimed at improving hydrogel scaffolds, especially relevant in neurodegenerative diseases' therapy.

Table 2. Summary of therapeutic agents delivered with scaffolds to treat neurodegenerative diseases.

\begin{tabular}{|c|c|c|c|}
\hline Disease & Molecules Delivery & Cells Delivery & Combined Delivery \\
\hline $\begin{array}{l}\text { Alzheimer } \\
\text { Disease }\end{array}$ & $\begin{array}{l}\text { Huperzine A, Tacrine, Nerve } \\
\text { Growth Factor, Estradiol, } \\
\text { Tempol, Donezepil [177-183] }\end{array}$ & Neural Stem Cells [155] & $\begin{array}{l}\text { Curcumin + Neuroprotective peptide, } \\
\text { Liposomes + hydrogels }[184,185]\end{array}$ \\
\hline $\begin{array}{l}\text { Parkinson's } \\
\text { Disease }\end{array}$ & $\begin{array}{l}\text { Dopamine, Glial } \\
\text { Cell-Derived Neurotrophic } \\
\text { Factor Hsp70, Activin-B, } \\
\text { Mesenchymal Stem Cells' } \\
\text { secretome [190-193,195] }\end{array}$ & $\begin{array}{l}\text { fetal Neural Stem Cells, } \\
\text { human Embryonic Stem } \\
\text { Cells, Mesenchymal } \\
\text { Stem Cells, induced } \\
\text { Pluripotent Stem Cells } \\
{[200-203,205]}\end{array}$ & $\begin{array}{c}\text { Dopaminergic neurons + Glial } \\
\text { Cell-Derived Neurotrophic Factor, } \\
\text { Neural Cells + Brain-derived } \\
\text { neurotrophic factor, } \\
\text { Hydrogels + Nanoparticles } \\
{[157,199,204]}\end{array}$ \\
\hline $\begin{array}{l}\text { Amyotrophic } \\
\text { Lateral Sclerosis }\end{array}$ & N/A & $\begin{array}{l}\text { Glial Progenitor cells } \\
\text { [219] }\end{array}$ & N/A \\
\hline $\begin{array}{c}\text { Acute } \\
\text { Ischemic Stroke }\end{array}$ & $\begin{array}{l}\text { Erythropoietin, Vascular } \\
\text { endothelial growth factor, } \\
\text { Brain-derived neurotrophic } \\
\text { factor, Cyclosporine A, } \\
\text { Genipin, Fibrin } \\
\text { [231,233-237,241-245] }\end{array}$ & $\begin{array}{c}\text { Neural Stem Cells, } \\
\text { Neural Precursor Stem } \\
\text { Cells, induced } \\
\text { Pluripotent Stem Cells, } \\
\text { Bone Marrow } \\
\text { Mesenchymal Cells } \\
{[159-162,224-227,229]}\end{array}$ & $\begin{array}{l}\text { Erythropoietin + Epidermal Growth } \\
\text { Factor, Vascular endothelial growth } \\
\text { factor + Angiopoietin [238-240] }\end{array}$ \\
\hline $\begin{array}{l}\text { Spinal Cord } \\
\text { Injury }\end{array}$ & $\begin{array}{l}\text { Neurotrophin-3, Nerve } \\
\text { Growth Factor, } \\
\text { Brain-derived neurotrophic } \\
\text { factor, Neuregulin [263-268] }\end{array}$ & $\begin{array}{l}\text { Human Mesenchymal } \\
\text { Stem Cells, Neural } \\
\text { Precursor Stem Cells } \\
{[166,269-273]}\end{array}$ & $\begin{array}{l}\text { Viral vectors + basic fibroblast growth } \\
\text { factor+ Epidermal Growth } \\
\text { Factor + Glial Cell-Derived } \\
\text { Neurotrophic Factor + integrin-blocking } \\
\text { antibody [170] }\end{array}$ \\
\hline
\end{tabular}

\section{Conclusions}

The characteristics of pathogenesis and lack of regenerative therapeutic approaches in neurodegenerative diseases implicates the need to develop new innovative therapeutic strategies. Additive manufacturing techniques have gained more and more relevance, proving the great potential of the fabrication of precision scaffolds, which could enhance therapeutic efficiency and even provide patient-specific 3-D scaffolds. This, together with the specific fabrication of scaffolds with precise 
geometry and structure, could prove of great importance in the field of regenerative medicine and neurodegenerative disease therapy.

Author Contributions: F.R., B.B., A.N. contributed to the design and the structure of the paper and wrote the manuscript; M.B. contributed to the literature collection; C.C. and G.V.Z. contributed to the critical review of the final manuscript; M.T.R. and S.C. contributed to the design and the structure of the paper and guided and critically reviewed the manuscript drafting; All authors have read and agreed to the published version of the manuscript.

Funding: This work was supported by Fondazione "Romeo and Enrica Invernizzi" to S.C. and G.V.Z. This project has received funding from the European Research Council (ERC) under the European Union's Horizon 2020 Research and Innovation program (G.A. n. 646990-NICHOID and G.A. n. 754467-NICHOIDS).

Acknowledgments: The authors are deeply grateful to Alfredo Gorio and Anna Maria Di Giulio (University of Milan, Italy) for their scientific support and unswerving encouragement to the work. FR would like to acknowledge and thank the Fondazione Fratelli Confalonieri for financial support during her PhD.

Conflicts of Interest: The authors declare that they have no conflict of interest.

\section{References}

1. Chan, B.P.; Leong, K.W. Scaffolding in tissue engineering: General approaches and tissue-specific considerations. Eur. Spine J. 2008, 17, 467-479. [CrossRef] [PubMed]

2. O'Brien, F.J. Biomaterials \& scaffolds for tissue engineering. Mater. Today 2011, 14, 88-95. [CrossRef]

3. Abdulghani, S.; Mitchell, G.R. Biomaterials for In Situ Tissue Regeneration: A Review. Biomolecules 2019, 9, 750. [CrossRef] [PubMed]

4. Khademhosseini, A.; Langer, R. A decade of progress in tissue engineering. Nat. Protoc. 2016, 11, 1775-1781. [CrossRef]

5. Langer, R.; Vacanti, J.P. Tissue engineering. Science 1993, 260, 920-926. [CrossRef] [PubMed]

6. Yeong, W.Y.; Chua, C.K.; Leong, K.F.; Chandrasekaran, M. Rapid prototyping in tissue engineering: Challenges and potential. Trends Biotechnol. 2004, 22, 643-652. [CrossRef] [PubMed]

7. Guzzi, E.A.; Tibbitt, M.W. Additive Manufacturing of Precision Biomaterials. Adv. Mater. 2019, 32, e1901994. [CrossRef]

8. Melchels, F.P.W.; Domingos, M.A.N.; Klein, T.J;; Malda, J.; Bartolo, P.J;; Hutmacher, D.W. Additive manufacturing of tissues and organs. Prog. Polym. Sci. 2012, 37, 1079-1104. [CrossRef]

9. Jeon, O.; Bin Lee, Y.; Hinton, T.J.; Feinberg, A.W.; Alsberg, E. Cryopreserved cell-laden alginate microgel bioink for 3D bioprinting of living tissues. Mater. Today Chem. 2019, 12, 61-70. [CrossRef]

10. Shick, T.M.; Abdul Kadir, A.Z.; Ngadiman, N.H.A.; Ma'aram, A. A review of biomaterials scaffold fabrication in additive manufacturing for tissue engineering. J. Bioact. Compat. Polym. 2019, 34, 415-435. [CrossRef]

11. Elbert, D.L. Bottom-Up tissue engineering. Curr. Opin. Biotechnol. 2011, 22, 674-680. [CrossRef] [PubMed]

12. Nichol, J.W.; Khademhosseini, A. Modular Tissue Engineering: Engineering Biological Tissues from the Bottom up. Soft Matter 2009, 5, 1312-1319. [CrossRef]

13. Markert, C.D.; Guo, X.; Skardal, A.; Wang, Z.; Bharadwaj, S.; Zhang, Y.; Bonin, K.; Guthold, M. Characterizing the micro-scale elastic modulus of hydrogels for use in regenerative medicine. J. Mech. Behav. Biomed. Mater. 2013, 27, 115-127. [CrossRef] [PubMed]

14. Rezwan, K.; Chen, Q.Z.; Blaker, J.J.; Boccaccini, A.R. Biodegradable and bioactive porous polymer/inorganic composite scaffolds for bone tissue engineering. Biomaterials 2006, 27, 3413-3431. [CrossRef] [PubMed]

15. Murdock, M.H.; Badylak, S.F. Biomaterials-based In Situ Tissue Engineering. Curr. Opin. Biomed. Eng. 2017, 1, 4-7. [CrossRef] [PubMed]

16. Hakkarainen, M.; Albertsson, A.-C. Degradation Products of Aliphatic and Aliphatic-Aromatic Polyesters. In Chromatography for Sustainable Polymeric Materials: Renewable, Degradable and Recyclable; Albertsson, A.-C., Hakkarainen, M., Eds.; Springer: Berlin/Heidelberg, Germany, 2008; pp. 85-116.

17. BaoLin, G.; Ma, P.X. Synthetic biodegradable functional polymers for tissue engineering: A brief review. Sci. China Chem. 2014, 57, 490-500. [CrossRef] [PubMed]

18. Magnusson, J.P.; Saeed, A.O.; Fernández-Trillo, F.; Alexander, C. Synthetic polymers for biopharmaceutical delivery. Polym. Chem. 2011, 2, 48-59. [CrossRef]

19. FDA. U.S. Food and Drug Administration. Available online: https://www.fda.gov/ (accessed on 30 June 2020). 
20. Pan, Z.; Ding, J. Poly(lactide-co-glycolide) porous scaffolds for tissue engineering and regenerative medicine. Interface Focus 2012, 2, 366-377. [CrossRef]

21. Xia, Z.; Jin, S.; Ye, K. Tissue and Organ 3D Bioprinting. SLAS Technol. 2018, 23, 301-314. [CrossRef]

22. Kim, S.S.; Sun Park, M.; Jeon, O.; Yong Choi, C.; Kim, B.S. Poly(Lactide-co-Glycolide)/hydroxyapatite composite scaffolds for bone tissue engineering. Biomaterials 2006, 27, 1399-1409. [CrossRef]

23. Wu, W.; Feng, X.; Mao, T.; Feng, X.; Ouyang, H.-W.; Zhao, G.; Chen, F. Engineering of human tracheal tissue with Collagen-Enforced Poly-Lactic-Glycolic acid non-Woven mesh: A preliminary study in nude mice. Br. J. Oral Maxillofac. Surg. 2007, 45, 272-278. [CrossRef] [PubMed]

24. Cao, W.; Hench, L.L. Bioactive materials. Ceram. Int. 1996, 22, 493-507. [CrossRef]

25. Wang, M. Developing bioactive composite materials for tissue replacement. Biomaterials 2003, 24, $2133-2151$. [CrossRef]

26. Meka, S.R.K.; Agarwal, V.; Chatterjee, K. In situ preparation of multicomponent polymer composite nanofibrous scaffolds with enhanced osteogenic and angiogenic activities. Mater. Sci. Eng. C Mater. Biol. Appl. 2019, 94, 565-579. [CrossRef] [PubMed]

27. Gilbert, T.W.; Sellaro, T.L.; Badylak, S.F. Decellularization of tissues and organs. Biomaterials 2006, 27, 3675-3683. [CrossRef]

28. Taylor, D.A.; Sampaio, L.C.; Ferdous, Z.; Gobin, A.S.; Taite, L.J. Decellularized matrices in regenerative medicine. Acta Biomater. 2018, 74, 74-89. [CrossRef]

29. Badylak, S.F.; Freytes, D.O.; Gilbert, T.W. Extracellular matrix as a biological scaffold material: Structure and function. Acta Biomater. 2009, 5, 1-13. [CrossRef]

30. Sachlos, E.; Czernuszka, J.T. Making tissue engineering scaffolds work. Review: The application of solid freeform fabrication technology to the production of tissue engineering scaffolds. Eur. Cell Mater. 2003, 5, 29-39, discussion 39-40. [CrossRef]

31. Peltola, S.M.; Melchels, F.P.; Grijpma, D.W.; Kellomäki, M. A review of rapid prototyping techniques for tissue engineering purposes. Ann. Med. 2008, 40, 268-280. [CrossRef]

32. Singh, M.; Jonnalagadda, S. Advances in bioprinting using additive manufacturing. Eur. J. Pharm. Sci. 2020, 143, 105167. [CrossRef]

33. Rider, P.; Kačarević, Ž.; Alkildani, S.; Retnasingh, S.; Barbeck, M. Bioprinting of tissue engineering scaffolds. J. Tissue Eng. 2018, 9, 2041731418802090. [CrossRef] [PubMed]

34. Kalaskar, D. 3D Printing in Medicine, 1st ed.; Woodhead: Sawston, UK, 2017; p. 178.

35. Vaezi, M.; Seitz, H.; Yang, S. Erratum to: A review on 3D micro-additive manufacturing technologies. Int. J. Adv. Manuf. Technol. 2013, 67, 1957. [CrossRef]

36. Sachs Emanuel, M.; Haggerty John, S.; Cima Michael, J.; Williams Paul, A. Three-Dimensional Printing Techniques. U.S. Patent 5,204,055 A, 8 December 1989.

37. Gittard, S.D.; Narayan, R.J. Laser direct writing of micro- and nano-scale medical devices. Expert Rev. Med. Devices 2010, 7, 343-356. [CrossRef] [PubMed]

38. Krüger, J.; Kautek, W. The Femtosecond Pulse Laser: A New Tool for Micromachining. Mod. Trends Laser Phys. 1999, 9, 30-40.

39. Kruth, J.-P.; Mercelis, P.; Van Vaerenbergh, J.; Froyen, L.; Rombouts, M. Binding mechanisms in selective laser sintering and selective laser melting. Rapid Prototyp. J. 2005, 11, 26-36. [CrossRef]

40. Zhang, X.; Jiang, X.N.; Sun, C. Micro-stereolithography of polymeric and ceramic microstructures. Sens. Actuators A Phys. 1999, 77, 149-156. [CrossRef]

41. Hitz, B.; Ewing, J.J.; Hecht, J. Introduction to Laser Technology, 3rd ed.; The Institute of Electrical and Electronics Engineers, Inc.: New York City, NY, USA, 2001.

42. Hribar, K.C.; Soman, P.; Warner, J.; Chung, P.; Chen, S. Light-assisted direct-write of 3D functional biomaterials. Lab Chip 2014, 14, 268-275. [CrossRef]

43. Antonov, E.N.; Bagratashvili, V.N.; Whitaker, M.J.; Barry, J.J.; Shakesheff, K.M.; Konovalov, A.N.; Popov, V.K.; Howdle, S.M. Three-Dimensional Bioactive and Biodegradable Scaffolds Fabricated by Surface-Selective Laser Sintering. Adv. Mater. 2004, 17, 327-330. [CrossRef]

44. Kathuria, Y.P. Microstructuring by selective laser sintering of metallic powder. Surf. Coat. Technol. 1999, 116-119, 643-647. [CrossRef] 
45. Kinstlinger, I.S.; Bastian, A.; Paulsen, S.J.; Hwang, D.H.; Ta, A.H.; Yalacki, D.R.; Schmidt, T.; Miller, J.S. Open-Source Selective Laser Sintering (OpenSLS) of Nylon and Biocompatible Polycaprolactone. PLoS ONE 2016, 11, e0147399. [CrossRef]

46. Venuvinod, P.K.; Ma, W. Rapid Prototyping. In Laser-Based and Other Technologies; Springer: New York, NY, USA, 2004; p. 390.

47. Gittard, S.D.; Nguyen, A.; Obata, K.; Koroleva, A.; Narayan, R.J.; Chichkov, B.N. Fabrication of microscale medical devices by two-photon polymerization with multiple foci via a spatial light modulator. Biomed. Opt. Express 2011, 2, 3167-3178. [CrossRef]

48. Doraiswamy, A.; Jin, C.; Narayan, R.J.; Mageswaran, P.; Mente, P.; Modi, R.; Auyeung, R.; Chrisey, D.B.; Ovsianikov, A.; Chichkov, B. Two photon induced polymerization of organic-inorganic hybrid biomaterials for microstructured medical devices. Acta Biomater. 2006, 2, 267-275. [CrossRef] [PubMed]

49. Serbin, J.; Egbert, A.; Ostendorf, A.; Chichkov, B.N.; Houbertz, R.; Domann, G.; Schulz, J.; Cronauer, C.; Fröhlich, L.; Popall, M. Femtosecond Laser-Induced Two-Photon polymerization of Inorganic-Organic hybrid materials for applications in photonics. Opt. Lett. 2003, 28, 301-303. [CrossRef]

50. Lee, K.-S.; Kim, R.H.; Yang, D.-Y.; Park, S.H. Advances in 3D nano/microfabrication using Two-Photon initiated polymerization. Prog. Polym. Sci. 2008, 33, 631-681. [CrossRef]

51. Ovsianikov, A.; Chichkov, B.; Adunka, O.; Pillsbury, H.; Doraiswamy, A.; Narayan, R.J. Rapid prototyping of ossicular replacement prostheses. Appl. Surf. Sci. 2007, 253, 6603-6607. [CrossRef]

52. Moroni, L.; Boland, T.; Burdick, J.A.; De Maria, C.; Derby, B.; Forgacs, G.; Groll, J.; Li, Q.; Malda, J.; Mironov, V.A.; et al. Biofabrication: A Guide to Technology and Terminology. Trends Biotechnol. 2018, 36, 384-402. [CrossRef]

53. Choonara, Y.E.; du Toit, L.C.; Kumar, P.; Kondiah, P.P.; Pillay, V. 3D-Printing and the effect on medical costs: A new era? Expert Rev. Pharm. Outcomes Res. 2016, 16, 23-32. [CrossRef] [PubMed]

54. Vaezi, M.; Chianrabutra, S.; Mellor, B.; Yang, S. Multiple material additive manufacturing_Part 1: A review. Virtual Phys. Prototyp. 2013, 8, 19-50. [CrossRef]

55. Cazón, A.; Morer, P.; Matey, L. PolyJet technology for product prototyping: Tensile strength and surface roughness properties. Proc. Inst. Mech. Eng. Part. B J. Eng. Manuf. 2014, 228, 1664-1675. [CrossRef]

56. Malda, J.; Visser, J.; Melchels, F.P.; Jüngst, T.; Hennink, W.E.; Dhert, W.J.; Groll, J.; Hutmacher, D.W. 25th anniversary article: Engineering hydrogels for biofabrication. Adv. Mater. 2013, 25, 5011-5028. [CrossRef]

57. Tibbitt, M.W.; Anseth, K.S. Hydrogels as extracellular matrix mimics for 3D cell culture. Biotechnol. Bioeng. 2009, 103, 655-663. [CrossRef]

58. Prendergast, M.E.; Solorzano, R.D.; Cabrera, D. Bioinks for biofabrication: Current state and future perspectives. J. 3D Print. Med. 2016, 1, 49-62. [CrossRef]

59. Derby, B. Printing and prototyping of tissues and scaffolds. Science 2012, 338, 921-926. [CrossRef] [PubMed]

60. Fedorovich, N.E.; Alblas, J.; de Wijn, J.R.; Hennink, W.E.; Verbout, A.J.; Dhert, W.J.A. Hydrogels as Extracellular Matrices for Skeletal Tissue Engineering: State-of-the-Art and Novel Application in Organ Printing. Tissue Eng. 2007, 13, 1905-1925. [CrossRef] [PubMed]

61. Nakamura, M.; Iwanaga, S.; Henmi, C.; Arai, K.; Nishiyama, Y. Biomatrices and biomaterials for future developments of bioprinting and biofabrication. Biofabrication 2010, 2, 014110. [CrossRef]

62. Chen, J.; Xu, J.; Wang, A.; Zheng, M. Scaffolds for tendon and ligament repair: Review of the efficacy of commercial products. Expert Rev. Med. Devices 2009, 6, 61-73. [CrossRef]

63. Ferris, C.J.; Gilmore, K.J.; Beirne, S.; McCallum, D.; Wallace, G.G.; in het Panhuis, M. Bio-ink for on-demand printing of living cells. Biomater. Sci. 2013, 1, 224-230. [CrossRef]

64. Xu, C.; Chai, W.; Huang, Y.; Markwald, R.R. Scaffold-Free inkjet printing of Three-Dimensional zigzag cellular tubes. Biotechnol. Bioeng. 2012, 109, 3152-3160. [CrossRef]

65. Hansen, C.J.; Saksena, R.; Kolesky, D.B.; Vericella, J.J.; Kranz, S.J.; Muldowney, G.P.; Christensen, K.T.; Lewis, J.A. High-Throughput Printing via Microvascular Multinozzle Arrays. Adv. Mater. 2013, 25, 96-102. [CrossRef]

66. Dababneh, A.B.; Ozbolat, I.T. Bioprinting Technology: A Current State-of-the-Art Review. J. Manuf. Sci. Eng. 2014, 136. [CrossRef]

67. Pati, F.; Jang, J.; Lee, J.W.; Cho, D.-W. Chapter 7-Extrusion Bioprinting. In Essentials of 3D Biofabrication and Translation; Atala, A., Yoo, J.J., Eds.; Academic Press: Boston, MA, USA, 2015; pp. 123-152. 
68. Ozbolat, I.T.; Hospodiuk, M. Current advances and future perspectives in extrusion-based bioprinting. Biomaterials 2016, 76, 321-343. [CrossRef] [PubMed]

69. Lee, J.; Lee, S.Y.; Jang, J.; Jeong, Y.H.; Cho, D.W. Fabrication of patterned nanofibrous mats using Direct-Write electrospinning. Langmuir 2012, 28, 7267-7275. [CrossRef] [PubMed]

70. Wang, W.; Li, G.; Huang, Y. Modeling of Bubble Expansion-Induced Cell Mechanical Profile in Laser-Assisted Cell Direct Writing; ASME: Evanston, IL, USA, 2008; pp. 505-514.

71. Li, J.; Chen, M.; Fan, X.; Zhou, H. Recent advances in bioprinting techniques: Approaches, applications and future prospects. J. Transl. Med. 2016, 14, 271. [CrossRef] [PubMed]

72. Guillemot, F.; Souquet, A.; Catros, S.; Guillotin, B.; Lopez, J.; Faucon, M.; Pippenger, B.; Bareille, R.; Rémy, M.; Bellance, S.; et al. High-Throughput laser printing of cells and biomaterials for tissue engineering. Acta Biomater. 2010, 6, 2494-2500. [CrossRef] [PubMed]

73. Gudapati, H.; Yan, J.; Huang, Y.; Chrisey, D.B. Alginate Gelation-Induced cell death during Laser-Assisted cell printing. Biofabrication 2014, 6, 035022. [CrossRef]

74. Gleadall, A.; Visscher, D.; Yang, J.; Thomas, D.; Segal, J. Review of additive manufactured tissue engineering scaffolds: Relationship between geometry and performance. Burn. Trauma 2018, 6, 19. [CrossRef]

75. Paz, R.; Monzón, M.D. Optimization methodology for the material assignation in bioprinted scaffolds to achieve the desired stiffness over time. Int. J. Numer Method Biomed. Eng. 2019, 35, e3248. [CrossRef]

76. Martino, F.; Perestrelo, A.R.; Vinarský, V.; Pagliari, S.; Forte, G. Cellular Mechanotransduction: From Tension to Function. Front. Physiol. 2018, 9, 824. [CrossRef]

77. Boeri, L.; Albani, D.; Raimondi, M.T.; Jacchetti, E. Mechanical regulation of nucleocytoplasmic translocation in mesenchymal stem cells: Characterization and methods for investigation. Biophys. Rev. 2019, 1-15. [CrossRef]

78. Muhamed, I.; Chowdhury, F.; Maruthamuthu, V. Biophysical Tools to Study Cellular Mechanotransduction. Bioengineering 2017, 4, 12. [CrossRef]

79. Mammoto, A.; Mammoto, T.; Ingber, D.E. Mechanosensitive mechanisms in transcriptional regulation. J. Cell Sci. 2012, 125, 3061-3073. [CrossRef] [PubMed]

80. Egan, P.F. Integrated Design Approaches for 3D Printed Tissue Scaffolds: Review and Outlook. Materials 2019, 12, 2355. [CrossRef] [PubMed]

81. Rodríguez-Montaño, Ó.; Cortés-Rodríguez, C.J.; Uva, A.E.; Fiorentino, M.; Gattullo, M.; Monno, G.; Boccaccio, A. Comparison of the mechanobiological performance of bone tissue scaffolds based on different unit cell geometries. J. Mech. Behav. Biomed. Mater. 2018, 83, 28-45. [CrossRef] [PubMed]

82. Brandl, F.; Sommer, F.; Goepferich, A. Rational design of hydrogels for tissue engineering: Impact of physical factors on cell behavior. Biomaterials 2007, 28, 134-146. [CrossRef]

83. Dado, D.; Levenberg, S. Cell-Scaffold mechanical interplay within engineered tissue. Semin. Cell Dev. Biol. 2009, 20, 656-664. [CrossRef]

84. Sobral, J.M.; Caridade, S.G.; Sousa, R.A.; Mano, J.F.; Reis, R.L. Three-Dimensional plotted scaffolds with controlled pore size gradients: Effect of scaffold geometry on mechanical performance and cell seeding efficiency. Acta Biomater. 2011, 7, 1009-1018. [CrossRef]

85. Shridhar, A.; Amsden, B.G.; Gillies, E.R.; Flynn, L.E. Investigating the Effects of Tissue-Specific Extracellular Matrix on the Adipogenic and Osteogenic Differentiation of Human Adipose-Derived Stromal Cells within Composite Hydrogel Scaffolds. Front. Bioeng. Biotechnol. 2019, 7, 402. [CrossRef]

86. Bobbert, F.S.L.; Lietaert, K.; Eftekhari, A.A.; Pouran, B.; Ahmadi, S.M.; Weinans, H.; Zadpoor, A.A. Additively manufactured metallic porous biomaterials based on minimal surfaces: A unique combination of topological, mechanical, and mass transport properties. Acta Biomater. 2017, 53, 572-584. [CrossRef]

87. Nikolova, M.P.; Chavali, M.S. Recent advances in biomaterials for 3D scaffolds: A review. Bioact. Mater. 2019, 4, 271-292. [CrossRef]

88. Polo-Corrales, L.; Latorre-Esteves, M.; Ramirez-Vick, J.E. Scaffold design for bone regeneration. J. Nanosci. Nanotechnol. 2014, 14, 15-56. [CrossRef]

89. Xu, X.; Lu, Y.; Li, S.; Guo, S.; He, M.; Luo, K.; Lin, J. Copper-modified Ti6Al4V alloy fabricated by selective laser melting with Pro-Angiogenic and Anti-Inflammatory properties for potential guided bone regeneration applications. Mater. Sci. Eng. C Mater. Biol. Appl. 2018, 90, 198-210. [CrossRef] [PubMed] 
90. Peng, W.M.; Liu, Y.F.; Jiang, X.F.; Dong, X.T.; Jun, J.; Baur, D.A.; Xu, J.J.; Pan, H.; Xu, X. Bionic mechanical design and 3D printing of novel porous Ti6Al4V implants for biomedical applications. J. Zhejiang Univ. Sci. B 2019, 20, 647-659. [CrossRef] [PubMed]

91. Byrne, D.P.; Lacroix, D.; Planell, J.A.; Kelly, D.J.; Prendergast, P.J. Simulation of tissue differentiation in a scaffold as a function of porosity, Young's modulus and dissolution rate: Application of mechanobiological models in tissue engineering. Biomaterials 2007, 28, 5544-5554. [CrossRef] [PubMed]

92. Zadpoor, A.A. Bone tissue regeneration: The role of scaffold geometry. Biomater. Sci. 2015, 3, 231-245. [CrossRef] [PubMed]

93. Aydin, H.M.; El Haj, A.J.; Pişkin, E.; Yang, Y. Improving pore interconnectivity in polymeric scaffolds for tissue engineering. J. Tissue Eng. Regen. Med. 2009, 3, 470-476. [CrossRef]

94. Zhao, D.; Huang, Y.; Ao, Y.; Han, C.; Wang, Q.; Li, Y.; Liu, J.; Wei, Q.; Zhang, Z. Effect of pore geometry on the fatigue properties and cell affinity of porous titanium scaffolds fabricated by selective laser melting. J. Mech. Behav. Biomed. Mater. 2018, 88, 478-487. [CrossRef]

95. Stoppato, M.; Carletti, E.; Maniglio, D.; Migliaresi, C.; Motta, A. Functional role of scaffold geometries as a template for physiological ECM formation: Evaluation of collagen 3D assembly. J. Tissue Eng. Regen. Med. 2013, 7, 161-168. [CrossRef]

96. Abbasi, N.; Ivanovski, S.; Gulati, K.; Love, R.M.; Hamlet, S. Role of offset and gradient architectures of 3-D melt electrowritten scaffold on differentiation and mineralization of osteoblasts. Biomater. Res. 2020, $24,2$. [CrossRef]

97. Goldstein, A.S.; Thayer, P.S. Chapter 11-Fabrication of complex biomaterial scaffolds for soft tissue engineering by electrospinning. In Nanobiomaterials in Soft Tissue Engineering; Grumezescu, A.M., Ed.; William Andrew: Norwich, NY, USA, 2016; pp. 299-330.

98. Lian, Q.; Li, D.C.; Chen, C.; Zhang, W.J.; Liu, Y.X.; He, J.K.; Jin, Z.M. Tissue-Engineered soft tissue oriented manufacturing technologies and additive manufacturing. Chin. J. Tissue Eng. Res. 2014, 18, 1263-1269.

99. Berry, D.B.; You, S.; Warner, J.; Frank, L.R.; Chen, S.; Ward, S.R. A 3D Tissue-Printing Approach for Validation of Diffusion Tensor Imaging in Skeletal Muscle. Tissue Eng. Part A 2017, 23, 980-988. [CrossRef]

100. Altomare, L.; Farè, S.; Tanzi, M.C. Chapter 7-Bio-Instructive Scaffolds for Muscle Regeneration: NonCrosslinked Polymers. In Bio-Instructive Scaffolds for Musculoskeletal Tissue Engineering and Regenerative Medicine; Brown, J.L., Kumbar, S.G., Banik, B.L., Eds.; Academic Press; Elsevier: Cambridge, MA, USA, 2017; pp. 161-186.

101. Jana, S.; Levengood, S.K.; Zhang, M. Anisotropic Materials for Skeletal-Muscle-Tissue Engineering. Adv. Mater. 2016, 28, 10588-10612. [CrossRef]

102. Tay, C.Y.; Wu, Y.-L.; Cai, P.; Tan, N.S.; Venkatraman, S.S.; Chen, X.; Tan, L.P. Bio-inspired micropatterned hydrogel to direct and deconstruct hierarchical processing of Geometry-Force signals by human mesenchymal stem cells during smooth muscle cell differentiation. Npg Asia Mater. 2015, 7, e199. [CrossRef]

103. Tsang, V.L.; Bhatia, S.N. Three-Dimensional tissue fabrication. Adv. Drug Deliv. Rev. 2004, 56, $1635-1647$. [CrossRef] [PubMed]

104. Bian, W.; Liau, B.; Badie, N.; Bursac, N. Mesoscopic hydrogel molding to control the 3D geometry of bioartificial muscle tissues. Nat. Protoc. 2009, 4, 1522-1534. [CrossRef] [PubMed]

105. Du, J.; Chen, H.; Qing, L.; Yang, X.; Jia, X. Biomimetic neural scaffolds: A crucial step towards optimal peripheral nerve regeneration. Biomater. Sci. 2018, 6, 1299-1311. [CrossRef] [PubMed]

106. Shahriari, D.; Loke, G.; Tafel, I.; Park, S.; Chiang, P.H.; Fink, Y.; Anikeeva, P. Scalable Fabrication of Porous Microchannel Nerve Guidance Scaffolds with Complex Geometries. Adv. Mater. 2019, 31, e1902021. [CrossRef]

107. Hoffman-Kim, D.; Mitchel, J.A.; Bellamkonda, R.V. Topography, cell response, and nerve regeneration. Annu. Rev. Biomed. Eng. 2010, 12, 203-231. [CrossRef]

108. Bellamkonda, R.V. Peripheral nerve regeneration: An opinion on channels, scaffolds and anisotropy. Biomaterials 2006, 27, 3515-3518. [CrossRef]

109. Zhao, C.; Lin, K.; Wang, X. Maintenance and modulation of stem cells stemness based on biomaterial designing via chemical and physical signals. Appl. Mater. Today 2020, 19, 100614. [CrossRef]

110. Raimondi, M.T.; Eaton, S.M.; Nava, M.M.; Laganà, M.; Cerullo, G.; Osellame, R. Two-Photon laser polymerization: From fundamentals to biomedical application in tissue engineering and regenerative medicine. J. Appl. Biomater. Funct. Mater. 2012, 10, 55-65. [CrossRef] 
111. Raimondi, M.T.; Nava, M.M.; Eaton, S.M.; Bernasconi, A.; Vishnubhatla, K.; Cerullo, G.; Osellame, R. Optimization of Femtosecond Laser Polymerized Structural Niches to Control Mesenchymal Stromal Cell Fate in Culture. Micromachines 2014, 5, 341-358. [CrossRef]

112. Nava, M.M.; Piuma, A.; Figliuzzi, M.; Cattaneo, I.; Bonandrini, B.; Zandrini, T.; Cerullo, G.; Osellame, R.; Remuzzi, A.; Raimondi, M.T. Two-Photon polymerized "nichoid" substrates maintain function of pluripotent stem cells when expanded under feeder-free conditions. Stem Cell Res. 2016, 7, 132. [CrossRef] [PubMed]

113. Nava, M.M.; Di Maggio, N.; Zandrini, T.; Cerullo, G.; Osellame, R.; Martin, I.; Raimondi, M.T. Synthetic niche substrates engineered via Two-Photon laser polymerization for the expansion of human mesenchymal stromal cells. J. Tissue Eng. Regen. Med. 2016, 11, 2836-2845. [CrossRef]

114. Nava, M.M.; Raimondi, M.T.; Pietrabissa, R. Controlling Self-Renewal and differentiation of stem cells via mechanical cues. J. Biomed. Biotechnol. 2012, 2012, 797410. [CrossRef]

115. Wanjare, M.; Hou, L.; Nakayama, K.H.; Kim, J.J.; Mezak, N.P.; Abilez, O.J.; Tzatzalos, E.; Wu, J.C.; Huang, N.F. Anisotropic microfibrous scaffolds enhance the organization and function of cardiomyocytes derived from induced pluripotent stem cells. Biomater. Sci. 2017, 5, 1567-1578. [CrossRef] [PubMed]

116. Zhang, Z.Z.; Chen, Y.R.; Wang, S.J.; Zhao, F.; Wang, X.G.; Yang, F.; Shi, J.J.; Ge, Z.G.; Ding, W.Y.; Yang, Y.C.; et al. Orchestrated biomechanical, structural, and biochemical stimuli for engineering anisotropic meniscus. Sci. Transl. Med. 2019, 11. [CrossRef] [PubMed]

117. Sivolella, S.; Brunello, G.; Ferrarese, N.; Della Puppa, A.; D’Avella, D.; Bressan, E.; Zavan, B. Nanostructured guidance for peripheral nerve injuries: A review with a perspective in the oral and maxillofacial area. Int. J. Mol. Sci. 2014, 15, 3088-3117. [CrossRef] [PubMed]

118. Kim, S.E.; Harker, E.C.; De Leon, A.C.; Advincula, R.C.; Pokorski, J.K. Coextruded, aligned, and Gradient-Modified poly(E-Caprolactone) fibers as platforms for neural growth. Biomacromolecules 2015, 16, 860-867. [CrossRef] [PubMed]

119. Fricke, R.; Zentis, P.D.; Rajappa, L.T.; Hofmann, B.; Banzet, M.; Offenhäusser, A.; Meffert, S.H. Axon guidance of rat cortical neurons by microcontact printed gradients. Biomaterials 2011, 32, 2070-2076. [CrossRef]

120. Jang, M.J.; Nam, Y. Geometric effect of cell adhesive polygonal micropatterns on neuritogenesis and axon guidance. J. Neural Eng. 2012, 9, 046019. [CrossRef]

121. Kim, D.; Kim, S.M.; Lee, S.; Yoon, M.H. Investigation of neuronal pathfinding and construction of artificial neuronal networks on 3D-Arranged porous fibrillar scaffolds with controlled geometry. Sci. Rep. 2017, 7, 7716. [CrossRef] [PubMed]

122. Wen, Y.Q.; Gao, X.; Wang, A.; Yang, Y.; Liu, S.; Yu, Z.; Song, G.B.; Zhao, H.C. Substrate stiffness affects neural network activity in an extracellular matrix proteins dependent manner. Colloids Surf. B Biointerfaces 2018, 170, 729-735. [CrossRef]

123. Leipzig, N.D.; Shoichet, M.S. The effect of substrate stiffness on adult neural stem cell behavior. Biomaterials 2009, 30, 6867-6878. [CrossRef]

124. Her, G.J.; Wu, H.C.; Chen, M.H.; Chen, M.Y.; Chang, S.C.; Wang, T.W. Control of three-dimensional substrate stiffness to manipulate mesenchymal stem cell fate toward neuronal or glial lineages. Acta Biomater. 2013, 9 , 5170-5180. [CrossRef] [PubMed]

125. Moxon, S.R.; Corbett, N.J.; Fisher, K.; Potjewyd, G.; Domingos, M.; Hooper, N.M. Blended alginate/collagen hydrogels promote neurogenesis and neuronal maturation. Mater. Sci. Eng. C Mater. Biol. Appl. 2019, 104, 109904. [CrossRef] [PubMed]

126. Lourenço, T.; Grãos, M. Modulation of Oligodendrocyte Differentiation by Mechanotransduction. Front. Cell Neurosci. 2016, 10, 277. [CrossRef] [PubMed]

127. Saha, K.; Irwin, E.F.; Kozhukh, J.; Schaffer, D.V.; Healy, K.E. Biomimetic interfacial interpenetrating polymer networks control neural stem cell behavior. J. Biomed. Mater. Res. A 2007, 81, 240-249. [CrossRef]

128. Bordoni, M.; Rey, F.; Fantini, V.; Pansarasa, O.; Di Giulio, A.M.; Carelli, S.; Cereda, C. From Neuronal Differentiation of iPSCs to 3D Neuro-Organoids: Modelling and Therapy of Neurodegenerative Diseases. Int. J. Mol. Sci. 2018, 19, 3972. [CrossRef] [PubMed]

129. Murphy, A.R.; Laslett, A.; O’Brien, C.M.; Cameron, N.R. Scaffolds for 3D in vitro culture of neural lineage cells. Acta Biomater. 2017, 54, 1-20. [CrossRef] [PubMed]

130. Solozobova, V.; Wyvekens, N.; Pruszak, J. Lessons from the embryonic neural stem cell niche for neural lineage differentiation of pluripotent stem cells. Stem Cell Rev. Rep. 2012, 8, 813-829. [CrossRef] [PubMed] 
131. Bordoni, M.; Scarian, E.; Rey, F.; Gagliardi, S.; Carelli, S.; Pansarasa, O.; Cereda, C. Biomaterials in Neurodegenerative Disorders: A Promising Therapeutic Approach. Int. J. Mol. Sci. 2020, 21, 3243. [CrossRef] [PubMed]

132. McCrary, M.W.; Bousalis, D.; Mobini, S.; Song, Y.H.; Schmidt, C.E. Decellularized tissues as platforms for in vitro modeling of healthy and diseased tissues. Acta Biomater. 2020, 111, 1-19. [CrossRef] [PubMed]

133. Reginensi, D.; Ortiz, D.; Pravia, A.; Burillo, A.; Morales, F.; Morgan, C.; Jimenez, L.; Dave, K.R.; Perez-Pinzon, M.A.; Gittens, R.A. Role of Region-Specific Brain Decellularized Extracellular Matrix on. Tissue Eng. Part. A 2020. [CrossRef] [PubMed]

134. Beachley, V.; Ma, G.; Papadimitriou, C.; Gibson, M.; Corvelli, M.; Elisseeff, J. Extracellular matrix particle-glycosaminoglycan composite hydrogels for regenerative medicine applications. J. Biomed. Mater. Res. A 2018, 106, 147-159. [CrossRef] [PubMed]

135. Cho, A.N.; Jin, Y.; Kim, S.; Kumar, S.; Shin, H.; Kang, H.C.; Cho, S.W. Aligned Brain Extracellular Matrix Promotes Differentiation and Myelination of Human-Induced Pluripotent Stem Cell-Derived Oligodendrocytes. ACS Appl. Mater. Interfaces 2019, 11, 15344-15353. [CrossRef]

136. Lin, Q.; Wong, H.L.; Tian, F.R.; Huang, Y.D.; Xu, J.; Yang, J.J.; Chen, P.P.; Fan, Z.L.; Lu, C.T.; Zhao, Y.Z. Enhanced neuroprotection with decellularized brain extracellular matrix containing bFGF after intracerebral transplantation in Parkinson's disease rat model. Int. J. Pharm. 2017, 517, 383-394. [CrossRef]

137. Tukmachev, D.; Forostyak, S.; Koci, Z.; Zaviskova, K.; Vackova, I.; Vyborny, K.; Sandvig, I.; Sandvig, A.; Medberry, C.J.; Badylak, S.F.; et al. Injectable Extracellular Matrix Hydrogels as Scaffolds for Spinal Cord Injury Repair. Tissue Eng. Part A 2016, 22, 306-317. [CrossRef]

138. Ruoslahti, E. Brain extracellular matrix. Glycobiology 1996, 6, 489-492. [CrossRef]

139. Lozano, R.; Stevens, L.; Thompson, B.C.; Gilmore, K.J.; Gorkin, R.; Stewart, E.M.; in het Panhuis, M.; Romero-Ortega, M.; Wallace, G.G. 3D printing of layered Brain-Like structures using peptide modified gellan gum substrates. Biomaterials 2015, 67, 264-273. [CrossRef]

140. Lee, J.W.; Lee, K.Y. Dual peptide-presenting hydrogels for controlling the phenotype of PC12 cells. Colloids Surf. $B$ Biointerfaces 2017, 152, 36-41. [CrossRef]

141. Roehm, K.D.; Madihally, S.V. Bioprinted chitosan-gelatin thermosensitive hydrogels using an inexpensive 3D printer. Biofabrication 2017, 10, 015002. [CrossRef]

142. Bordoni, M.; Karabulut, E.; Kuzmenko, V.; Fantini, V.; Pansarasa, O.; Cereda, C.; Gatenholm, P. 3D Printed Conductive Nanocellulose Scaffolds for the Differentiation of Human Neuroblastoma Cells. Cells 2020, 9, 682. [CrossRef] [PubMed]

143. Kuzmenko, V.; Kalogeropoulos, T.; Thunberg, J.; Johannesson, S.; Hägg, D.; Enoksson, P.; Gatenholm, P. Enhanced growth of neural networks on conductive cellulose-derived nanofibrous scaffolds. Mater. Sci. Eng. C Mater. Biol. Appl. 2016, 58, 14-23. [CrossRef] [PubMed]

144. Wang, J.; Cheng, Y.; Chen, L.; Zhu, T.; Ye, K.; Jia, C.; Wang, H.; Zhu, M.; Fan, C.; Mo, X. In vitro and in vivo studies of electroactive reduced graphene Oxide-Modified nanofiber scaffolds for peripheral nerve regeneration. Acta Biomater. 2019, 84, 98-113. [CrossRef] [PubMed]

145. Nune, M.; Manchineella, S.; Govindaraju, T.; Narayan, K.S. Melanin incorporated electroactive and antioxidant silk fibroin nanofibrous scaffolds for nerve tissue engineering. Mater. Sci. Eng. C Mater. Biol. Appl. 2019, 94, 17-25. [CrossRef]

146. Barroca, N.; Marote, A.; Vieira, S.I.; Almeida, A.; Fernandes, M.H.V.; Vilarinho, P.M.; da Cruz, E.S.O.A.B. Electrically polarized PLLA nanofibers as neural tissue engineering scaffolds with improved neuritogenesis. Colloids Surf. B Biointerfaces 2018, 167, 93-103. [CrossRef]

147. Büyüköz, M.; Erdal, E.; Alsoy Altinkaya, S. Nanofibrous gelatine scaffolds integrated with nerve growth factor-loaded alginate microspheres for brain tissue engineering. J. Tissue Eng. Regen. Med. 2018, 12, e707-e719. [CrossRef]

148. Koss, K.; Tsui, C.; Unsworth, L.D. Induced Neural Differentiation of MMP-2 Cleaved (RADA)(4) Drug Delivery Systems. J. Control. Release 2016, 243, 204-213. [CrossRef]

149. Tavakol, S.; Saber, R.; Hoveizi, E.; Tavakol, B.; Aligholi, H.; Ai, J.; Rezayat, S.M. Self-Assembling Peptide Nanofiber Containing Long Motif of Laminin Induces Neural Differentiation, Tubulin Polymerization, and Neurogenesis: In Vitro, ex Vivo, and in Vivo Studies. Mol. Neurobiol. 2016, 53, 5288-5299. [CrossRef] 
150. Zhang, Z.-N.; Freitas, B.C.; Qian, H.; Lux, J.; Acab, A.; Trujillo, C.A.; Herai, R.H.; Huu, V.A.N.; Wen, J.H.; Joshi-Barr, S. Layered hydrogels accelerate iPSC-Derived neuronal maturation and reveal migration defects caused by MeCP2 dysfunction. Proc. Natl. Acad. Sci. USA 2016, 113, 3185-3190. [CrossRef]

151. Fantini, V.; Bordoni, M.; Scocozza, F.; Conti, M.; Scarian, E.; Carelli, S.; Di Giulio, A.M.; Marconi, S.; Pansarasa, O.; Auricchio, F.; et al. Bioink Composition and Printing Parameters for 3D Modeling Neural Tissue. Cells 2019, 8, 830. [CrossRef] [PubMed]

152. Mosley, M.C.; Lim, H.J.; Chen, J.; Yang, Y.H.; Li, S.; Liu, Y.; Smith Callahan, L.A. Neurite extension and neuronal differentiation of human induced pluripotent stem cell derived neural stem cells on polyethylene glycol hydrogels containing a continuous Young's Modulus gradient. J. Biomed. Mater. Res. A 2017, 105, 824-833. [CrossRef] [PubMed]

153. Fan, L.; Liu, C.; Chen, X.; Zou, Y.; Zhou, Z.; Lin, C.; Tan, G.; Zhou, L.; Ning, C.; Wang, Q. Directing induced pluripotent stem cell derived neural stem cell fate with a Three-Dimensional biomimetic hydrogel for spinal cord injury repair. ACS Appl. Mater. Interfaces 2018, 10, 17742-17755. [CrossRef] [PubMed]

154. Nazari, B.; Kazemi, M.; Kamyab, A.; Ebrahimi-Barough, S.; Hadjighassem, M.; Norouzi-Javidan, A.; Ai, A.; Ahmadi, A.; Ai, J. Fibrin hydrogel as a scaffold for differentiation of induced pluripotent stem cells into oligodendrocytes. J. Biomed. Mater. Res. B Appl. Biomater. 2020, 108, 192-200. [CrossRef]

155. Cui, G.H.; Shao, S.J.; Yang, J.J.; Liu, J.R.; Guo, H.D. Designer Self-Assemble Peptides Maximize the Therapeutic Benefits of Neural Stem Cell Transplantation for Alzheimer's Disease via Enhancing Neuron Differentiation and Paracrine Action. Mol. Neurobiol. 2016, 53, 1108-1123. [CrossRef]

156. Giordano, C.; Albani, D.; Gloria, A.; Tunesi, M.; Batelli, S.; Russo, T.; Forloni, G.; Ambrosio, L.; Cigada, A. Multidisciplinary perspectives for Alzheimer's and Parkinson's diseases: Hydrogels for protein delivery and cell-based drug delivery as therapeutic strategies. Int. J. Artif. Organs 2009, 32, 836-850. [CrossRef]

157. Sudo, J.; Iwase, H.; Terui, J.; Kakuno, K.; Soyama, M.; Takayama, K.; Nagai, T. Transdermal absorption of L-dopa from hydrogel in rats. Eur. J. Pharm. Sci. 1998, 7, 67-71. [CrossRef]

158. Moriarty, N.; Pandit, A.; Dowd, E. Encapsulation of primary dopaminergic neurons in a GDNF-Loaded collagen hydrogel increases their survival, Re-Innervation and function after intra-striatal transplantation. Sci. Rep. 2017, 7, 16033. [CrossRef]

159. Park, K.I.; Teng, Y.D.; Snyder, E.Y. The injured brain interacts reciprocally with neural stem cells supported by scaffolds to reconstitute lost tissue. Nat. Biotechnol. 2002, 20, 1111-1117. [CrossRef]

160. Zhong, J.; Chan, A.; Morad, L.; Kornblum, H.I.; Fan, G.; Carmichael, S.T. Hydrogel matrix to support stem cell survival after brain transplantation in stroke. Neurorehabilit. Neural Repair 2010, 24, 636-644. [CrossRef]

161. Wei, Z.; Zhao, J.; Chen, Y.M.; Zhang, P.; Zhang, Q. Self-Healing Polysaccharide-Based hydrogels as injectable carriers for neural stem cells. Sci. Rep. 2016, 6, 37841. [CrossRef] [PubMed]

162. Jin, K.; Mao, X.; Xie, L.; Greenberg, R.B.; Peng, B.; Moore, A.; Greenberg, M.B.; Greenberg, D.A. Delayed transplantation of human neural precursor cells improves outcome from focal cerebral ischemia in aged rats. Aging Cell 2010, 9, 1076-1083. [CrossRef]

163. Katoh, H.; Yokota, K.; Fehlings, M.G. Regeneration of Spinal Cord Connectivity through Stem Cell Transplantation and Biomaterial Scaffolds. Front. Cell Neurosci. 2019, 13, 248. [CrossRef] [PubMed]

164. Elliott Donaghue, I.; Tam, R.; Sefton, M.V.; Shoichet, M.S. Cell and biomolecule delivery for tissue repair and regeneration in the central nervous system. J. Control. Release 2014, 190, 219-227. [CrossRef] [PubMed]

165. Sakiyama-Elbert, S.; Johnson, P.J.; Hodgetts, S.I.; Plant, G.W.; Harvey, A.R. Scaffolds to promote spinal cord regeneration. Handb. Clin. Neurol. 2012, 109, 575-594. [CrossRef] [PubMed]

166. Li, X.; Liu, D.; Xiao, Z.; Zhao, Y.; Han, S.; Chen, B.; Dai, J. Scaffold-Facilitated locomotor improvement post complete spinal cord injury: Motor axon regeneration versus endogenous neuronal relay formation. Biomaterials 2019, 197, 20-31. [CrossRef]

167. Badhiwala, J.H.; Ahuja, C.S.; Fehlings, M.G. Time is spine: A review of translational advances in spinal cord injury. J. Neurosurg. Spine 2018, 30,1-18. [CrossRef]

168. Theodore, N.; Hlubek, R.; Danielson, J.; Neff, K.; Vaickus, L.; Ulich, T.R.; Ropper, A.E. First Human Implantation of a Bioresorbable Polymer Scaffold for Acute Traumatic Spinal Cord Injury: A Clinical Pilot Study for Safety and Feasibility. Neurosurgery 2016, 79, E305-E312. [CrossRef]

169. Moriarty, N.; Dowd, E. Brain repair for Parkinson's disease: Is the answer in the matrix? Neural Regen. Res. 2018, 13, 1187-1188. [CrossRef] 
170. Anderson, M.A.; O'Shea, T.M.; Burda, J.E.; Ao, Y.; Barlatey, S.L.; Bernstein, A.M.; Kim, J.H.; James, N.D.; Rogers, A.; Kato, B.; et al. Required growth facilitators propel axon regeneration across complete spinal cord injury. Nature 2018, 561, 396-400. [CrossRef]

171. Carlson, A.L.; Bennett, N.K.; Francis, N.L.; Halikere, A.; Clarke, S.; Moore, J.C.; Hart, R.P.; Paradiso, K.; Wernig, M.; Kohn, J.; et al. Generation and transplantation of reprogrammed human neurons in the brain using 3D microtopographic scaffolds. Nat. Commun. 2016, 7, 10862. [CrossRef]

172. Chemmarappally, J.M.; Pegram, H.C.N.; Abeywickrama, N.; Fornari, E.; Hargreaves, A.J.; De Girolamo, L.A.; Stevens, B. A Co-Culture nanofibre scaffold model of neural cell degeneration in relevance to Parkinson's disease. Sci. Rep. 2020, 10, 2767. [CrossRef] [PubMed]

173. Karch, C.M.; Cruchaga, C.; Goate, A.M. Alzheimer's disease genetics: From the bench to the clinic. Neuron 2014, 83, 11-26. [CrossRef]

174. Scheltens, P.; Blennow, K.; Breteler, M.M.; de Strooper, B.; Frisoni, G.B.; Salloway, S.; Van der Flier, W.M. Alzheimer's disease. Lancet 2016, 388, 505-517. [CrossRef]

175. Blennow, K.; de Leon, M.J.; Zetterberg, H. Alzheimer's disease. Lancet 2006, 368, 387-403. [CrossRef]

176. Hadavi, D.; Poot, A.A. Biomaterials for the Treatment of Alzheimer's Disease. Front. Bioeng. Biotechnol. 2016, 4, 49. [CrossRef]

177. Gao, P.; Xu, H.; Ding, P.; Gao, Q.; Sun, J.; Chen, D. Controlled release of huperzine A from biodegradable microspheres: In vitro and in vivo studies. Int. J. Pharm. 2007, 330, 1-5. [CrossRef] [PubMed]

178. Jogani, V.V.; Shah, P.J.; Mishra, P.; Mishra, A.K.; Misra, A.R. Intranasal mucoadhesive microemulsion of tacrine to improve brain targeting. Alzheimer Dis. Assoc. Disord. 2008, 22, 116-124. [CrossRef]

179. Setya, S.; Madaan, T.; Razdan, B.K.; Farswan, M.; Talegaonkar, S. Design and Development of Novel Transdermal Nanoemulgel for Alzheimer's Disease: Pharmacokinetic, Pharmacodynamic and Biochemical Investigations. Curr. Drug Deliv. 2019, 16, 902-912. [CrossRef]

180. Gu, H.; Long, D.; Song, C.; Li, X. Recombinant human NGF-loaded microspheres promote survival of basal forebrain cholinergic neurons and improve memory impairments of spatial learning in the rat model of Alzheimer's disease with Fimbria-Fornix lesion. Neurosci. Lett. 2009, 453, 204-209. [CrossRef]

181. Mittal, G.; Carswell, H.; Brett, R.; Currie, S.; Kumar, M.N. Development and evaluation of polymer nanoparticles for oral delivery of estradiol to rat brain in a model of Alzheimer's pathology. J. Control. Release 2011, 150, 220-228. [CrossRef] [PubMed]

182. Carroll, R.T.; Bhatia, D.; Geldenhuys, W.; Bhatia, R.; Miladore, N.; Bishayee, A.; Sutariya, V. Brain-targeted delivery of Tempol-loaded nanoparticles for neurological disorders. J. Drug Target. 2010, 18, 665-674. [CrossRef]

183. Al Harthi, S.; Alavi, S.E.; Radwan, M.A.; El Khatib, M.M.; AlSarra, I.A. Nasal delivery of donepezil HCl-loaded hydrogels for the treatment of Alzheimer's disease. Sci. Rep. 2019, 9, 9563. [CrossRef]

184. Adak, A.; Das, G.; Barman, S.; Mohapatra, S.; Bhunia, D.; Jana, B.; Ghosh, S. Biodegradable Neuro-Compatible Peptide Hydrogel Promotes Neurite Outgrowth, Shows Significant Neuroprotection, and Delivers Anti-Alzheimer Drug. ACS Appl. Mater. Interfaces 2017, 9, 5067-5076. [CrossRef] [PubMed]

185. Adnet, T.; Groo, A.C.; Picard, C.; Davis, A.; Corvaisier, S.; Since, M.; Bounoure, F.; Rochais, C.; Pluart, L.L.; Dallemagne, P.; et al. Pharmacotechnical Development of a Nasal Drug Delivery Composite Nanosystem Intended for Alzheimer's Disease Treatment. Pharmaceutics 2020, 12, 251. [CrossRef] [PubMed]

186. Wirdefeldt, K.; Adami, H.O.; Cole, P.; Trichopoulos, D.; Mandel, J. Epidemiology and etiology of Parkinson's disease: A review of the evidence. Eur. J. Epidemiol. 2011, 26 (Suppl. S1), 1. [CrossRef]

187. Benskey, M.J.; Perez, R.G.; Manfredsson, F.P. The contribution of alpha synuclein to neuronal survival and function-Implications for Parkinson's disease. J. Neurochem. 2016, 137, 331-359. [CrossRef]

188. Nutt, J.G.; Wooten, G.F. Clinical practice. Diagnosis and initial management of Parkinson's disease. N. Engl. J. Med. 2005, 353, 1021-1027. [CrossRef]

189. Stoker, T.B.; Torsney, K.M.; Barker, R.A. Emerging Treatment Approaches for Parkinson's Disease. Front. Neurosci. 2018, 12, 693. [CrossRef]

190. Senthilkumar, K.S.; Saravanan, K.S.; Chandra, G.; Sindhu, K.M.; Jayakrishnan, A.; Mohanakumar, K.P. Unilateral implantation of Dopamine-Loaded biodegradable hydrogel in the striatum attenuates motor abnormalities in the 6-Hydroxydopamine model of Hemi-Parkinsonism. Behav. Brain Res. 2007, 184, 11-18. [CrossRef] 
191. Aubert-Pouëssel, A.; Venier-Julienne, M.C.; Clavreul, A.; Sergent, M.; Jollivet, C.; Montero-Menei, C.N.; Garcion, E.; Bibby, D.C.; Menei, P.; Benoit, J.P. In vitro study of GDNF release from biodegradable PLGA microspheres. J. Control. Release 2004, 95, 463-475. [CrossRef] [PubMed]

192. Wang, T.Y.; Bruggeman, K.F.; Kauhausen, J.A.; Rodriguez, A.L.; Nisbet, D.R.; Parish, C.L. Functionalized composite scaffolds improve the engraftment of transplanted dopaminergic progenitors in a mouse model of Parkinson's disease. Biomaterials 2016, 74, 89-98. [CrossRef] [PubMed]

193. Tunesi, M.; Raimondi, I.; Russo, T.; Colombo, L.; Micotti, E.; Brandi, E.; Cappelletti, P.; Cigada, A.; Negro, A.; Ambrosio, L.; et al. Hydrogel-Based delivery of Tat-fused protein Hsp70 protects dopaminergic cells in vitro and in a mouse model of Parkinson's disease. Npg Asia Mater. 2019, 11, 28. [CrossRef]

194. Li, J.; Darabi, M.; Gu, J.; Shi, J.; Xue, J.; Huang, L.; Liu, Y.; Zhang, L.; Liu, N.; Zhong, W.; et al. A drug delivery hydrogel system based on activin B for Parkinson's disease. Biomaterials 2016, 102, 72-86. [CrossRef] [PubMed]

195. Chierchia, A.; Chirico, N.; Boeri, L.; Raimondi, I.; Riva, G.A.; Raimondi, M.T.; Tunesi, M.; Giordano, C.; Forloni, G.; Albani, D. Secretome released from hydrogel-embedded adipose mesenchymal stem cells protects against the Parkinson's disease related toxin 6-hydroxydopamine. Eur. J. Pharm. Biopharm. 2017, 121, 113-120. [CrossRef] [PubMed]

196. González, C.; Bonilla, S.; Flores, A.I.; Cano, E.; Liste, I. An Update on Human Stem Cell-Based Therapy in Parkinson's Disease. Curr. Stem Cell Res. 2016, 11, 561-568. [CrossRef]

197. Carelli, S.; Giallongo, T.; Gombalova, Z.; Rey, F.; Gorio, M.C.F.; Mazza, M.; Di Giulio, A.M. Counteracting neuroinflammation in experimental Parkinson's disease favors recovery of function: Effects of Er-NPCs administration. J. Neuroinflammation 2018, 15, 333. [CrossRef]

198. Nakaji-Hirabayashi, T.; Kato, K.; Iwata, H. Hyaluronic acid hydrogel loaded with Genetically-Engineered Brain-Derived neurotrophic factor as a neural cell carrier. Biomaterials 2009, 30, 4581-4589. [CrossRef]

199. Nakaji-Hirabayashi, T.; Kato, K.; Iwata, H. Self-assembling chimeric protein for the construction of biodegradable hydrogels capable of interaction with integrins expressed on neural stem/progenitor cells. Biomacromolecules 2008, 9, 1411-1416. [CrossRef]

200. Moriyasu, K.; Yamazoe, H.; Iwata, H. Induction dopamine releasing cells from mouse embryonic stem cells and their long-term culture. J. Biomed. Mater. Res. A 2006, 77, 136-147. [CrossRef]

201. Thonhoff, J.R.; Lou, D.I.; Jordan, P.M.; Zhao, X.; Wu, P. Compatibility of human fetal neural stem cells with hydrogel biomaterials in vitro. Brain Res. 2008, 1187, 42-51. [CrossRef]

202. Adil, M.M.; Vazin, T.; Ananthanarayanan, B.; Rodrigues, G.M.C.; Rao, A.T.; Kulkarni, R.U.; Miller, E.W.; Kumar, S.; Schaffer, D.V. Engineered hydrogels increase the Post-Transplantation survival of encapsulated Hesc-Derived midbrain dopaminergic neurons. Biomaterials 2017, 136, 1-11. [CrossRef] [PubMed]

203. Albani, D.; Gloria, A.; Giordano, C.; Rodilossi, S.; Russo, T.; D’Amora, U.; Tunesi, M.; Cigada, A.; Ambrosio, L.; Forloni, G. Hydrogel-based nanocomposites and mesenchymal stem cells: A promising synergistic strategy for neurodegenerative disorders therapy. Sci. World J. 2013, 2013, 270260. [CrossRef] [PubMed]

204. Giordano, C.; Albani, D.; Gloria, A.; Tunesi, M.; Rodilossi, S.; Russo, T.; Forloni, G.; Ambrosio, L.; Cigada, A. Nanocomposites for neurodegenerative diseases: Hydrogel-Nanoparticle combinations for a challenging drug delivery. Int. J. Artif. Organs 2011, 34, 1115-1127. [CrossRef]

205. Komatsu, M.; Konagaya, S.; Egawa, E.Y.; Iwata, H. Maturation of human iPS cell-derived dopamine neuron precursors in Alginate-Ca(2+) hydrogel. Biochim. Biophys. Acta 2015, 1850, 1669-1675. [CrossRef] [PubMed]

206. Wijesekera, L.C.; Leigh, P.N. Amyotrophic lateral sclerosis. Orphanet J. Rare Dis. 2009, 4, 3. [CrossRef]

207. Kiernan, M.C.; Vucic, S.; Cheah, B.C.; Turner, M.R.; Eisen, A.; Hardiman, O.; Burrell, J.R.; Zoing, M.C. Amyotrophic lateral sclerosis. Lancet 2011, 377, 942-955. [CrossRef]

208. Hall, C.E.; Yao, Z.; Choi, M.; Tyzack, G.E.; Serio, A.; Luisier, R.; Harley, J.; Preza, E.; Arber, C.; Crisp, S.J.; et al. Progressive Motor Neuron Pathology and the Role of Astrocytes in a Human Stem Cell Model of VCP-Related ALS. Cell Rep. 2017, 19, 1739-1749. [CrossRef]

209. Madill, M.; McDonagh, K.; Ma, J.; Vajda, A.; McLoughlin, P.; O’Brien, T.; Hardiman, O.; Shen, S. Amyotrophic lateral sclerosis patient iPSC-derived astrocytes impair autophagy via non-cell autonomous mechanisms. Mol. Brain 2017, 10, 22. [CrossRef]

210. Centeno, E.G.Z.; Cimarosti, H.; Bithell, A. 2D versus 3D human induced pluripotent stem Cell-Derived cultures for neurodegenerative disease modelling. Mol. Neurodegener. 2018, 13, 27. [CrossRef] 
211. Berthod, F.; Gros-Louis, F. In Vivo and In Vitro Models to Study Amyotrophic Lateral Sclerosis; Maurer, M., Ed.; InTech: London, UK, 2012.

212. Gingras, M.; Beaulieu, M.M.; Gagnon, V.; Durham, H.D.; Berthod, F. In vitro study of axonal migration and myelination of motor neurons in a Three-Dimensional Tissue-Engineered model. Glia 2008, 56, 354-364. [CrossRef] [PubMed]

213. Cheema, U.; Yang, S.Y.; Mudera, V.; Goldspink, G.G.; Brown, R.A. 3-D in vitro model of early skeletal muscle development. Cell Motil. Cytoskelet. 2003, 54, 226-236. [CrossRef]

214. Evans, R.M.; Harridge, S.D.; Velloso, C.P.; Yang, S.Y.; Goldspink, G.; Orrell, R.W. Investigation of MGF mRNA expression in patients with amyotrophic lateral sclerosis using parallel in vivo and in vitro approaches. Amyotroph. Lateral Scler. 2010, 11, 172-177. [CrossRef]

215. Zhao, A.; Pan, Y.; Cai, S. Patient-Specific Cells for Modeling and Decoding Amyotrophic Lateral Sclerosis: Advances and Challenges. Stem Cell Rev. Rep. 2020, 1-21. [CrossRef] [PubMed]

216. Lai, B.Q.; Feng, B.; Che, M.T.; Wang, L.J.; Cai, S.; Huang, M.Y.; Gu, H.Y.; Jiang, B.; Ling, E.A.; Li, M.; et al. A Modular Assembly of Spinal Cord-Like Tissue Allows Targeted Tissue Repair in the Transected Spinal Cord. Adv. Sci. 2018, 5, 1800261. [CrossRef] [PubMed]

217. Bowser, D.A.; Moore, M.J. Biofabrication of neural microphysiological systems using magnetic spheroid bioprinting. Biofabrication 2019, 12, 015002. [CrossRef]

218. Liu, J.; Fu, T.M.; Cheng, Z.; Hong, G.; Zhou, T.; Jin, L.; Duvvuri, M.; Jiang, Z.; Kruskal, P.; Xie, C.; et al. Syringe-Injectable electronics. Nat. Nanotechnol. 2015, 10, 629-636. [CrossRef]

219. Malysz-Cymborska, I.; Golubczyk, D.; Kalkowski, L.; Burczyk, A.; Janowski, M.; Holak, P.; Olbrych, K.; Sanford, J.; Stachowiak, K.; Milewska, K.; et al. MRI-Guided intrathecal transplantation of Hydrogel-Embedded glial progenitors in large animals. Sci. Rep. 2018, 8, 16490. [CrossRef] [PubMed]

220. Dirnagl, U.; Iadecola, C.; Moskowitz, M.A. Pathobiology of ischaemic stroke: An integrated view. Trends Neurosci. 1999, 22, 391-397. [CrossRef]

221. Ruscher, K.; Isaev, N.; Trendelenburg, G.; Weih, M.; Iurato, L.; Meisel, A.; Dirnagl, U. Induction of hypoxia inducible factor 1 by oxygen glucose deprivation is attenuated by hypoxic preconditioning in rat cultured neurons. Neurosci. Lett. 1998, 254, 117-120. [CrossRef]

222. Modo, M. Bioscaffold-Induced Brain Tissue Regeneration. Front. Neurosci. 2019, 13, 1156. [CrossRef] [PubMed]

223. Gopalakrishnan, A.; Shankarappa, S.A.; Rajanikant, G.K. Hydrogel Scaffolds: Towards Restitution of Ischemic Stroke-Injured Brain. Transl. Stroke Res. 2019, 10, 1-18. [CrossRef] [PubMed]

224. Bible, E.; Chau, D.Y.; Alexander, M.R.; Price, J.; Shakesheff, K.M.; Modo, M. The support of neural stem cells transplanted into stroke-induced brain cavities by PLGA particles. Biomaterials 2009, 30, 2985-2994. [CrossRef]

225. Bible, E.; Dell'Acqua, F.; Solanky, B.; Balducci, A.; Crapo, P.M.; Badylak, S.F.; Ahrens, E.T.; Modo, M. Non-Invasive imaging of transplanted human neural stem cells and ECM scaffold remodeling in the Stroke-Damaged rat brain by (19)F- and Diffusion-MRI. Biomaterials 2012, 33, 2858-2871. [CrossRef]

226. Musah, S.; Wrighton, P.J.; Zaltsman, Y.; Zhong, X.; Zorn, S.; Parlato, M.B.; Hsiao, C.; Palecek, S.P.; Chang, Q.; Murphy, W.L.; et al. Substratum-Induced differentiation of human pluripotent stem cells reveals the coactivator YAP is a potent regulator of neuronal specification. Proc. Natl. Acad. Sci. USA 2014, 111, 13805-13810. [CrossRef] [PubMed]

227. Zhang, H.; Sun, F.; Wang, J.; Xie, L.; Yang, C.; Pan, M.; Shao, B.; Yang, G.Y.; Yang, S.H.; ZhuGe, Q.; et al. Combining Injectable Plasma Scaffold with Mesenchymal Stem/Stromal Cells for Repairing Infarct Cavity after Ischemic Stroke. Aging Dis. 2017, 8, 203-214. [CrossRef]

228. Benedek, A.; Cernica, D.; Mester, A.; Opincariu, D.; Hodas, R.; Rodean, I.; Keri, J.; Benedek, T. Modern Concepts in Regenerative Therapy for Ischemic Stroke: From Stem Cells for Promoting Angiogenesis to 3D-Bioprinted Scaffolds Customized via Carotid Shear Stress Analysis. Int. J. Mol. Sci. 2019, 20, 2574. [CrossRef]

229. Jin, K.; Mao, X.; Xie, L.; Galvan, V.; Lai, B.; Wang, Y.; Gorostiza, O.; Wang, X.; Greenberg, D.A. Transplantation of human neural precursor cells in Matrigel scaffolding improves outcome from focal cerebral ischemia after delayed postischemic treatment in rats. J. Cereb. Blood Flow Metab. 2010, 30, 534-544. [CrossRef]

230. Boisserand, L.S.; Kodama, T.; Papassin, J.; Auzely, R.; Moisan, A.; Rome, C.; Detante, O. Biomaterial Applications in Cell-Based Therapy in Experimental Stroke. Stem Cells Int. 2016, 2016, 6810562. [CrossRef]

231. Wang, Y.; Cooke, M.J.; Morshead, C.M.; Shoichet, M.S. Hydrogel delivery of erythropoietin to the brain for endogenous stem cell stimulation after stroke injury. Biomaterials 2012, 33, 2681-2692. [CrossRef] 
232. Rey, F.; Balsari, A.; Giallongo, T.; Ottolenghi, S.; Di Giulio, A.M.; Samaja, M.; Carelli, S. Erythropoietin as a Neuroprotective Molecule: An Overview of Its Therapeutic Potential in Neurodegenerative Diseases. ASN Neuro 2019, 11. [CrossRef] [PubMed]

233. Emerich, D.F.; Silva, E.; Ali, O.; Mooney, D.; Bell, W.; Yu, S.J.; Kaneko, Y.; Borlongan, C. Injectable VEGF hydrogels produce near complete neurological and anatomical protection following cerebral ischemia in rats. Cell Transplant. 2010, 19, 1063-1071. [CrossRef] [PubMed]

234. Yamashita, T.; Deguchi, K.; Nagotani, S.; Abe, K. Vascular protection and restorative therapy in ischemic stroke. Cell Transplant. 2011, 20, 95-97. [CrossRef] [PubMed]

235. Cook, D.J.; Nguyen, C.; Chun, H.N.; L Llorente, I.; Chiu, A.S.; Machnicki, M.; Zarembinski, T.I.; Carmichael, S.T. Hydrogel-Delivered Brain-Derived neurotrophic factor promotes tissue repair and recovery after stroke. J. Cereb. Blood Flow Metab. 2017, 37, 1030-1045. [CrossRef]

236. Tuladhar, A.; Morshead, C.M.; Shoichet, M.S. Circumventing the Blood-Brain barrier: Local delivery of cyclosporin A stimulates stem cells in stroke-injured rat brain. J. Control. Release 2015, 215, 1-11. [CrossRef]

237. Caicco, M.J.; Cooke, M.J.; Wang, Y.; Tuladhar, A.; Morshead, C.M.; Shoichet, M.S. A hydrogel composite system for sustained Epi-Cortical delivery of Cyclosporin A to the brain for treatment of stroke. J. Control. Release 2013, 166, 197-202. [CrossRef]

238. Cooke, M.J.; Wang, Y.; Morshead, C.M.; Shoichet, M.S. Controlled Epi-Cortical delivery of epidermal growth factor for the stimulation of endogenous neural stem cell proliferation in stroke-injured brain. Biomaterials 2011, 32, 5688-5697. [CrossRef]

239. Wang, Y.; Cooke, M.J.; Sachewsky, N.; Morshead, C.M.; Shoichet, M.S. Bioengineered sequential growth factor delivery stimulates brain tissue regeneration after stroke. J. Control. Release 2013, 172, 1-11. [CrossRef]

240. Ju, R.; Wen, Y.; Gou, R.; Wang, Y.; Xu, Q. The experimental therapy on brain ischemia by improvement of local angiogenesis with tissue engineering in the mouse. Cell Transplant. 2014, 23 (Suppl. S1), 83-95. [CrossRef]

241. Wang, Z.; Wang, J.; Jin, Y.; Luo, Z.; Yang, W.; Xie, H.; Huang, K.; Wang, L. A Neuroprotective Sericin Hydrogel as an Effective Neuronal Cell Carrier for the Repair of Ischemic Stroke. ACS Appl. Mater. Interfaces 2015, 7, 24629-24640. [CrossRef]

242. Navaei-Nigjeh, M.; Amoabedini, G.; Noroozi, A.; Azami, M.; Asmani, M.N.; Ebrahimi-Barough, S.; Saberi, H.; Ai, A.; Ai, J. Enhancing neuronal growth from human endometrial stem cells derived Neuron-Like cells in three-dimensional fibrin gel for nerve tissue engineering. J. Biomed. Mater. Res. A 2014, 102, 2533-2543. [CrossRef] [PubMed]

243. Arulmoli, J.; Wright, H.J.; Phan, D.T.T.; Sheth, U.; Que, R.A.; Botten, G.A.; Keating, M.; Botvinick, E.L.; Pathak, M.M.; Zarembinski, T.I.; et al. Combination scaffolds of salmon fibrin, hyaluronic acid, and laminin for human neural stem cell and vascular tissue engineering. Acta Biomater. 2016, 43, 122-138. [CrossRef] [PubMed]

244. Chen, S.J.; Chang, C.M.; Tsai, S.K.; Chang, Y.L.; Chou, S.J.; Huang, S.S.; Tai, L.K.; Chen, Y.C.; Ku, H.H.; Li, H.Y.; et al. Functional improvement of focal cerebral ischemia injury by subdural transplantation of induced pluripotent stem cells with fibrin glue. Stem Cells Dev. 2010, 19, 1757-1767. [CrossRef] [PubMed]

245. Ma, T.; Wang, Y.; Qi, F.; Zhu, S.; Huang, L.; Liu, Z.; Huang, J.; Luo, Z. The effect of synthetic oxygen Carrier-Enriched fibrin hydrogel on Schwann cells under hypoxia condition in vitro. Biomaterials 2013, 34, 10016-10027. [CrossRef]

246. Massensini, A.R.; Ghuman, H.; Saldin, L.T.; Medberry, C.J.; Keane, T.J.; Nicholls, F.J.; Velankar, S.S.; Badylak, S.F.; Modo, M. Concentration-dependent rheological properties of ECM hydrogel for intracerebral delivery to a stroke cavity. Acta Biomater. 2015, 27, 116-130. [CrossRef]

247. Profyris, C.; Cheema, S.S.; Zang, D.; Azari, M.F.; Boyle, K.; Petratos, S. Degenerative and regenerative mechanisms governing spinal cord injury. Neurobiol. Dis. 2004, 15, 415-436. [CrossRef]

248. McDonald, J.W.; Sadowsky, C. Spinal-Cord injury. Lancet 2002, 359, 417-425. [CrossRef]

249. Furlan, J.C.; Noonan, V.; Cadotte, D.W.; Fehlings, M.G. Timing of decompressive surgery of spinal cord after traumatic spinal cord injury: An evidence-based examination of Pre-Clinical and clinical studies. J. Neurotrauma 2011, 28, 1371-1399. [CrossRef]

250. Ahuja, C.S.; Nori, S.; Tetreault, L.; Wilson, J.; Kwon, B.; Harrop, J.; Choi, D.; Fehlings, M.G. Traumatic Spinal Cord Injury-Repair and Regeneration. Neurosurgery 2017, 80, S9-S22. [CrossRef] 
251. Rooney, G.E.; Vaishya, S.; Ameenuddin, S.; Currier, B.L.; Schiefer, T.K.; Knight, A.; Chen, B.; Mishra, P.K.; Spinner, R.J.; Macura, S.I.; et al. Rigid fixation of the spinal column improves scaffold alignment and prevents scoliosis in the transected rat spinal cord. Spine 2008, 33, 914-919. [CrossRef]

252. Silva, N.A.; Sousa, R.A.; Fraga, J.S.; Fontes, M.; Leite-Almeida, H.; Cerqueira, R.; Almeida, A.; Sousa, N.; Reis, R.L.; Salgado, A.J. Benefits of spine stabilization with biodegradable scaffolds in spinal cord injured rats. Tissue Eng. Part C Methods 2013, 19, 101-108. [CrossRef] [PubMed]

253. Pawar, K.; Cummings, B.J.; Thomas, A.; Shea, L.D.; Levine, A.; Pfaff, S.; Anderson, A.J. Biomaterial bridges enable regeneration and Re-Entry of corticospinal tract axons into the caudal spinal cord after SCI: Association with recovery of forelimb function. Biomaterials 2015, 65, 1-12. [CrossRef] [PubMed]

254. Chedly, J.; Soares, S.; Montembault, A.; von Boxberg, Y.; Veron-Ravaille, M.; Mouffle, C.; Benassy, M.N.; Taxi, J.; David, L.; Nothias, F. Physical chitosan microhydrogels as scaffolds for spinal cord injury restoration and axon regeneration. Biomaterials 2017, 138, 91-107. [CrossRef]

255. Amani, H.; Kazerooni, H.; Hassanpoor, H.; Akbarzadeh, A.; Pazoki-Toroudi, H. Tailoring synthetic polymeric biomaterials towards nerve tissue engineering: A review. Artif. Cells Nanomed. Biotechnol. 2019, 47, 3524-3539. [CrossRef] [PubMed]

256. Zhang, Q.; Shi, B.; Ding, J.; Yan, L.; Thawani, J.P.; Fu, C.; Chen, X. Polymer scaffolds facilitate spinal cord injury repair. Acta Biomater. 2019, 88, 57-77. [CrossRef]

257. Mattei, T.A. How graphene is expected to impact neurotherapeutics in the near future. Expert Rev. Neurother. 2014, 14, 845-847. [CrossRef]

258. Domínguez-Bajo, A.; González-Mayorga, A.; López-Dolado, E.; Serrano, M.C. Graphene-Derived Materials Interfacing the Spinal Cord: Outstanding. Front. Syst. Neurosci. 2017, 11, 71. [CrossRef]

259. Kim, C.Y.; Sikkema, W.K.; Hwang, I.K.; Oh, H.; Kim, U.J.; Lee, B.H.; Tour, J.M. Spinal cord fusion with PEG-GNRs (TexasPEG): Neurophysiological recovery in 24 h in rats. Surg. Neurol. Int. 2016, 7, $632-636$. [CrossRef]

260. Dalamagkas, K.; Tsintou, M.; Seifalian, A.; Seifalian, A.M. Translational Regenerative Therapies for Chronic Spinal Cord Injury. Int. J. Mol. Sci. 2018, 19, 1776. [CrossRef]

261. Carelli, S.; Giallongo, T.; Rey, F.; Colli, M.; Tosi, D.; Bulfamante, G.; Di Giulio, A.M.; Gorio, A. Neuroprotection, Recovery of Function and Endogenous Neurogenesis in Traumatic Spinal Cord Injury Following Transplantation of Activated Adipose Tissue. Cells 2019, 8, 329. [CrossRef]

262. Betz, V.M.; Sitoci-Ficici, K.H.; Uckermann, O.; Leipnitz, E.; Iltzsche, A.; Thirion, C.; Salomon, M.; Zwipp, H.; Schackert, G.; Betz, O.B.; et al. Gene-activated fat grafts for the repair of spinal cord injury: A pilot study. Acta Neurochir. 2016, 158, 367-378. [CrossRef] [PubMed]

263. Yang, Z.; Zhang, A.; Duan, H.; Zhang, S.; Hao, P.; Ye, K.; Sun, Y.E.; Li, X. NT3-Chitosan elicits robust endogenous neurogenesis to enable functional recovery after spinal cord injury. Proc. Natl. Acad. Sci. USA 2015, 112, 13354-13359. [CrossRef] [PubMed]

264. Rao, J.S.; Zhao, C.; Zhang, A.; Duan, H.; Hao, P.; Wei, R.H.; Shang, J.; Zhao, W.; Liu, Z.; Yu, J.; et al. NT3-Chitosan enables de novo regeneration and functional recovery in monkeys after spinal cord injury. Proc. Natl. Acad. Sci. USA 2018, 115, E5595-E5604. [CrossRef]

265. Oudega, M.; Hao, P.; Shang, J.; Haggerty, A.E.; Wang, Z.; Sun, J.; Liebl, D.J.; Shi, Y.; Cheng, L.; Duan, H.; et al. Validation study of neurotrophin-3-releasing chitosan facilitation of neural tissue generation in the severely injured adult rat spinal cord. Exp. Neurol. 2019, 312, 51-62. [CrossRef]

266. Song, B.; Song, J.; Zhang, S.; Anderson, M.A.; Ao, Y.; Yang, C.Y.; Deming, T.J.; Sofroniew, M.V. Sustained local delivery of bioactive nerve growth factor in the central nervous system via tunable diblock copolypeptide hydrogel depots. Biomaterials 2012, 33, 9105-9116. [CrossRef]

267. Ghosh, B.; Wang, Z.; Nong, J.; Urban, M.W.; Zhang, Z.; Trovillion, V.A.; Wright, M.C.; Zhong, Y.; Lepore, A.C. Local BDNF Delivery to the Injured Cervical Spinal Cord using an Engineered Hydrogel Enhances Diaphragmatic Respiratory Function. J. Neurosci. 2018, 38, 5982-5995. [CrossRef] [PubMed]

268. Santhosh, K.T.; Alizadeh, A.; Karimi-Abdolrezaee, S. Design and optimization of PLGA microparticles for controlled and local delivery of Neuregulin-1 in traumatic spinal cord injury. J. Control. Release 2017, 261, 147-162. [CrossRef] [PubMed]

269. Ropper, A.E.; Thakor, D.K.; Han, I.; Yu, D.; Zeng, X.; Anderson, J.E.; Aljuboori, Z.; Kim, S.W.; Wang, H.; Sidman, R.L.; et al. Defining recovery neurobiology of injured spinal cord by synthetic Matrix-Assisted hMSC implantation. Proc. Natl. Acad. Sci. USA 2017, 114, E820-E829. [CrossRef] [PubMed] 
270. Xiao, Z.; Tang, F.; Zhao, Y.; Han, G.; Yin, N.; Li, X.; Chen, B.; Han, S.; Jiang, X.; Yun, C.; et al. Significant Improvement of Acute Complete Spinal Cord Injury Patients Diagnosed by a Combined Criteria Implanted with NeuroRegen Scaffolds and Mesenchymal Stem Cells. Cell Transplant. 2018, 27, 907-915. [CrossRef]

271. Yousefifard, M.; Nasseri Maleki, S.; Askarian-Amiri, S.; Vaccaro, A.R.; Chapman, J.R.; Fehlings, M.G.; Hosseini, M.; Rahimi-Movaghar, V. A combination of mesenchymal stem cells and scaffolds promotes motor functional recovery in spinal cord injury: A systematic review and Meta-Analysis. J. Neurosurg. Spine 2019, 32, 269-284. [CrossRef]

272. Koffler, J.; Zhu, W.; Qu, X.; Platoshyn, O.; Dulin, J.N.; Brock, J.; Graham, L.; Lu, P.; Sakamoto, J.; Marsala, M.; et al. Biomimetic 3D-Printed scaffolds for spinal cord injury repair. Nat. Med. 2019, 25, 263-269. [CrossRef] [PubMed]

273. Yang, L.; Chueng, S.D.; Li, Y.; Patel, M.; Rathnam, C.; Dey, G.; Wang, L.; Cai, L.; Lee, K.B. A biodegradable hybrid inorganic nanoscaffold for advanced stem cell therapy. Nat. Commun. 2018, 9, 3147. [CrossRef] [PubMed]

(C) 2020 by the authors. Licensee MDPI, Basel, Switzerland. This article is an open access article distributed under the terms and conditions of the Creative Commons Attribution (CC BY) license (http://creativecommons.org/licenses/by/4.0/). 